\title{
Caracterização hidroquímica de águas superficiais dos rios Guajiru e do Mudo, Bacia Hidrográfica do rio Doce, RN, Nordeste do Brasil
}

\author{
Micael Batista DAMASCENO', Raquel Franco de SOUZA², José Braz DINIZ FILHO² \& \\ Vera Lúcia Lopes de CASTRO3 \\ 1 Instituto Federal de Educação, Ciência e Tecnologia do Rio Grande do Norte. Campus Natal Central, Av. \\ Senador Salgado Filho, 1559, Tirol, CEP 59015-000, Natal, RN, Brasil (damasceno.micael@ifrn.edu.br). \\ 2 Departamento de Geologia da Universidade Federal do Rio Grande do Norte. Campus Universitário, rua \\ das Engenharias, s/n, Lagoa Nova, CEP 59078-970, Natal, RN, Brasil (raquel@geologia.ufrn.br, \\ brazdf@geologia.ufrn.br). \\ ${ }^{3}$ Escola de Ciências e Tecnologia da Universidade Federal do Rio Grande do Norte. Campus Universitário, \\ s/n, Lagoa Nova, CEP 59078-970, Natal, RN, Brasil (veracastro@ect.ufrn.br).
}

\begin{abstract}
Resumo. A Bacia Hidrográfica do rio Doce contém os tributários rio do Mudo e rio Guajiru. É uma das principais bacias do Litoral Oriental do Estado do Rio Grande do Norte, tendo em vista ser responsável pela formação da lagoa de Extremoz, a qual abastece parte da região metropolitana de Natal/RN. Vem sofrendo ao longo dos anos intensa pressão por parte da ocupação humana e industrialização. Parte da região das nascentes é composta por rochas do embasamento Précambriano (e.g. granitos e ortognaisses), predominando no restante rochas sedimentares da Formação Barreiras e materiais Quaternários. Foram estabelecidos oito pontos de amostragens nas sub bacias dos rios Guajiru e do Mudo, onde foi coletada água, no período de julho a agosto de 2016, para classificação hidroquímica e correlação de suas características com os aspectos litológicos. O diagrama de Piper classificou as amostras predominantemente como cloretadas sódicas. Os diagramas de Stiff e Radiais mostram agrupamentos das amostras, tendo relacionamento genético com as regiões de nascente. A partir dos Sólidos Totais Dissolvidos - STDs as águas foram classificadas predominantemente como salgadas e salobras. As razões iônicas caracterizaram águas associadas a rochas cristalinas gnáissicas e graníticas. Os diagramas de Gibbs mostraram a influência do processo de evaporação/cristalização na química das águas. As águas estudadas (salgadas/salobras) nessa porção das nascentes demonstram ser quimicamente distintas das águas superficiais do médio e baixo curso da bacia hidrográfica, nos quais se têm águas doces/potáveis (usadas inclusive para consumo humano), devido a perenização dos rios/vales efluentes com águas doces do aquífero Barreiras.
\end{abstract}

Palavras-chave. Diagramas Hidroquímicos, Razões lônicas, Qualidade de Água.

\begin{abstract}
HYDROCHEMICAL CHARACTERIZATION OF SURFACE WATERS OF THE GUAJIRU AND MUdo RIVERS, DOCE RIVER WATERSHED, RN, NORTHEASTERN BRAZIL. The Doce River watershed contains the tributaries Mudo River and Guajiru River, that form the Doce River. It is one of the main basins of the Eastern Coast of the Rio Grande do Norte State, as it is responsible for the formation of Extremoz Lagoon, which in turn supplies part of the metropolitan region of Natal/ $\mathrm{RN}$. The watershed has suffered over the years intense pressure from the human occupation and industrialization in the region. Part of the area of the springs is composed by rocks of the preCambrian basement (e.g. granites and granitic gneisses), being predominant in the remaining area the sedimentary rocks of the Barreiras Formation and Quaternary materials. Eight sampling points were set up in the Mudo and Guajiru river sub-basins, where water was collected, between July and August 2016, to classify them hydrochemically and to correlate their characteristics with the lithological aspects. The Piper diagram classified the samples predominantly as sodium chlorine type. The Stiff and Radial diagrams show groupings of the samples, having genetic relationship with the nascent regions. From the TDSs the waters were classified predominantly as salted and brackish. Ionic ratios characterized waters associated with crystalline gneissic and granitic rocks. The Gibbs diagrams showed the influence of the evaporation / crystallization process on the water chemistry. The studied waters (salty / brackish) in this part of the springs show to be chemically different from the surface waters of the middle and lower course of the river basin, where there are fresh / potable waters (used for human consumption), due to the perpetuation of the effluent rivers / valleys with fresh waters of the Barreiras aquifer.
\end{abstract}

Keywords. Hydro chemical diagrams; Ionic Reasons; Water Quality. 


\section{Introdução}

As bacias hidrográficas integram o conjunto de superfícies delimitadas por divisores topográficos e são constituídas por canais e tributários, que drenam a pluviosidade, os sedimentos e as substâncias dissolvidas para um canal principal, cuja vazão converge em uma saída única, o exutório (Lima, 1976). Elas compõem um sistema natural aberto, sujeito às ações das condições naturais e antrópicas (Cunha \& Guerra, 2012).

A atividade humana nas proximidades de lagos e rios têm influência direta nas características físico-químicas das águas. A poluição dos rios, o lançamento de efluentes gerados pelas diversas atividades humanas, bem como interferências no fluxo de água nas bacias hidrográficas podem alterar drasticamente a composição química e o ecossistema de um meio natural.

Levando em consideração a origem dos elementos químicos dissolvidos nas águas naturais, Hem (1986) observou que uma grande fonte de íons dissolvidos na água é a assembleia mineral das rochas próximas a superfície. 0 autor argumenta que diversos fatores como composição das rochas, a pureza e tamanho dos cristais minerais, a textura e porosidade da rocha, a estrutura regional, o grau de fissuramento, o tempo de exposição entre outros fatores influenciam na composição da água que passa sobre e através da rocha.

A Bacia Hidrográfica do rio Doce é uma das principais bacias do Litoral Oriental do estado do Rio Grande do Norte, ocupando uma área de aproximadamente $387 \mathrm{~km}^{2}$. Os afluentes que Ihe dão origem são o rio Guajiru, rio do Mudo, lagoa de Extremoz e o rio Doce (SERHID, 2006). Sendo a lagoa um manancial de água doce, sua conservação é estratégica para o abastecimento da região metropolitana de Natal.

As bacias hidrográficas do Litoral Oriental do estado do Rio Grande do Norte se apresentam, do montante até o médio curso, com áreas de transições entre as rochas do embasamento cristalino e rochas sedimentares. Assim, a caracterização da qualidade das águas nessas áreas de transições entre o meio poroso e o fraturado constitui um esforço valioso para garantir uma gestão racional dos recursos hídricos. O valor desses estudos se traduz na medida em que o conhecimento sobre as variações hidroquímicas das águas, e as relações água superficial/água subterrânea nessas áreas, fortalece cada vez mais os bancos de dados para uma administração inteligente dos recursos hídricos nas bacias do semiárido brasileiro. Essa possibilidade de contribuir para uma gestão coerente e participativa das águas tem seu valor na medida em que se torna possível estudar e divulgar o conhecimento dessas peculiaridades hidrogeológicas regionais e/ou locais, relacionadas aos aspectos quali-quantitativos dos recursos hídricos, no âmbito das próprias instituições de pesquisa, da sociedade, das instituições gestoras, dentre outros segmentos. Nessa perspectiva, têm sido desenvolvidas pesquisas, que tratam da caracterização hidroquímica das águas, no mundo todo, desde as produções das décadas passadas até as mais recentes como Aly (2014), Hamad et al. (2018), Sakram et al. (2018), Neissi et al. (2019), Li et al. (2020), Zhang et al. (2020).

Faustino et al. (2014) relatam que a Bacia Hidrográfica do rio Doce vem enfrentando, nos últimos 40 anos, modificações ambientais significativas, resultantes do desmatamento e da rápida ocupação humana, argumentando que existe uma demanda hídrica para abastecimento doméstico e industrial e que há nesta região problemas de erosão dos solos, e de poluição da água por rejeitos industriais. Oliveira (2006), Azevedo Filho (2012) e Nobrega et al. (2017) apontam em seus estudos para a necessidade de observação da qualidade da água dessa bacia, que se apresenta precária em algumas porções, tendo contaminação de metais traço e diminuição na qualidade das águas. A salinidade encontrada em alguns pontos pode ser alta. Costa et al. (2006) argumentam que a salinidade no ambiente cristalino granito-gnáissico tende a diminuir do Agreste (área em estudo) para a região Serrana do estado.

Diversos autores que estudaram corpos hídricos superficiais e águas subterrâneas do Nordeste do Brasil (Leprun, 1983; Silva Júnior et al., 1999; Silva et al., 2003; Lucena et al., 
2004; Medeiros, 2004; Melo et al., 2005; Pereira et al., 2006; Stein, 2013), e também outros que estudaram áreas áridas à semiáridas em outros países (Shanyengana et al., 2004; Jiang et al., 2015; Taheri et al., 2017; Qaisar et al., 2018; Zhang et al., 2019 e Li et al., 2020), relacionam a questão da alta salinidade em aquíferos e reservatórios hídricos à influência do clima, às rochas e aos processos controladores da química, como evaporação.

Este trabalho teve por objetivo caracterizar os aspectos hidroquímicos das águas superficiais do setor ocidental, que engloba as nascentes da bacia hidrográfica, e estimar a provável relação da litologia e/ou dos sedimentos superficiais com os parâmetros físicos e químicos da água. Os objetivos específicos foram o de fazer a classificação hidroquímica dos corpos d'água, com base em diagramas de Piper, Stiff e Radiais, além de caracterizar a salinidade das amostras e suas possíveis origens, com base nos Sólidos Totais Dissolvidos, Razões lônicas e Diagrama de Gibbs.

\section{2 Área, materiais e métodos}

\section{1 Localização da área}

Atividades prospectivas/reconhecimento em campo foram feitas anteriormente à fase de coleta de amostras, com o objetivo de delimitar a área de estudo. Nela foram reconhecidas de forma geral aspectos da geologia, da geomorfologia, dos solos e da vegetação.

Dentro dessa bacia foi delimitada uma área ocupando as sub-bacias do rio Guajiru e rio do Mudo. Esta área localiza-se entre as coordenadas UTM Zona 25S 212528 m e 239734 m E; 9360645 m e 9376500 m S (Fig. 1).

Foram definidos na área de pesquisa oito pontos de coleta de amostras de água, sendo quatro no rio do Mudo e quatro no rio Guajiru (Fig. 1). Esses pontos foram escolhidos em função da carência de estudos encontrados na bibliografia sobre águas superficiais no alto e médio curso da Bacia Hidrográfica do rio Doce, e pelo fato de alguns mananciais serem utilizados pelas populações locais para atividades diversas. Considerou-se também a facilidade de locomoção dentro da área da pesquisa, pela proximidade dos pontos com vias de acesso.

De fato, no baixo curso, a lagoa de Extremoz e o rio Doce são perenizados por ressurgência de águas subterrâneas do aquífero Barreiras. Neste domínio os registros hidroquímicos indicam baixa salinidade média, e águas de caráter doce e potável, conforme estudos de Castro (2000) e ANA (2012).

Quatro dos pontos estão na sub-bacia do rio do Mudo, sendo o M17, M18, M22 e M32; quatro estão na sub-bacia do rio Guajiru, sendo o M35, M36, M42 e M49 (Fig. 1). A numeração dos pontos é herdada de trabalhos prévios. As coordenadas de cada ponto foram adquiridas com GPS do modelo eTrex® ${ }^{\circledR}$ 10, marca Garmin, utilizando o Datum SIRGAS 2000, UTM zona 25S.

O mapa de localização (Fig. 1), juntamente com o esboço geológico da área, foi elaborado a partir da junção das cartas geológicas folhas Natal e João Câmara (CPRM, 2012a, 2013b); as legendas de cores e símbolos foram adaptadas para atender a representação do presente artigo. Para a delimitação da bacia hidrográfica em estudo, bem como as drenagens nela contidas, foi utilizado o proposto por Costa et al. (2016), que trata de uma atualização dessas feições.

No sentido de montante para jusante na sub-bacia do rio do Mudo, o ponto M32 encontrase em um barramento de córregos oriundos das nascentes, geologicamente sobre a Suíte Dona Inês (rochas graníticas), e com o solo do entorno composto essencialmente de quartzo. Os pontos M17 e M18 estão no mesmo contexto geológico do M32, com solos jovens, quartzosos, sem vegetação expressiva. O M22 difere dos pontos citados por ser água do aquífero, aflorante devido à abertura de uma piscina, em uma área com influência antrópica de casas de granjas próximas. Geologicamente está sobre coberturas sedimentares (rochas da Formação Barreiras).

Na sub-bacia do rio Guajiru o ponto M49 é uma pequena lagoa, com solo arenoso e pouca matéria orgânica, inserido geologicamente nas coberturas aluvionares. O M36 é uma lagoa perene no centro da comunidade de Serrinha, São Gonçalo do Amarante, comunidade essa produtora de brita e pedras de cantaria. Geologicamente está sobre a Suíte Dona 
Inês (rochas graníticas), com solo arenoso e quartzoso. Entretanto a cobertura do Barreiras já é significativa e pode contribuir com ressurgência para a lagoa. O M42 está localizado a montante de um barramento de um dos córregos da respectiva sub-bacia. Geologicamente está sobre o contexto de depósitos aluvionares. O M35 está em propriedade privada na comunidade de Maçaranduba, São Gonçalo do Amarante. Tratase de um olheiro em material coluvial do aquífero Barreiras, com solo areno-argiloso e pouca matéria orgânica.

Alguns representam acumulações superficiais de água (M17, M18 e M32) no momento da realização da coleta; outros são afloramentos naturais (M35) ou artificiais (M22) dos aquíferos que compõem o substrato da bacia; os pontos M42 e M49 se apresentam no domínio do aquífero Barreiras, sendo associados à contribuição/ressurgência subterrânea deste aquífero, enquanto que o M36 está inserido no domínio da Suíte Dona Inês, com provável contribuição de água do aquífero Barreiras

\subsection{Material}

Entre julho e agosto de 2016, foram coletadas nos pontos descritos, amostras de água para ensaios físicos e químicos e análises químicas, seguindo metodologia da Companhia Ambiental do Estado de São Paulo (CETESB) e da Agência Nacional de Águas (CETESB, 2011).

As amostras de água foram coletadas em garrafas de Politereftalato de Etileno (PET) de dois litros, previamente esterilizadas. O transporte das amostras foi feito em caixas isotérmicas refrigeradas. As amostras de água foram imediatamente levadas ao Laboratório de Análise de Solo, Água e Planta da Empresa de Pesquisa Agropecuária do Rio Grande do Norte (EMPARN), sendo aplicada a metodologia de análises baseadas na Standand Methods for the Examination of Water and Wastewater, 20th ed. 1998 (Eaton, 1998).

\subsection{Métodos}

Para classificação e comparação dos distintos grupos de amostras, quanto aos íons dominantes, foram feitos diagramas hidroquímicos de Piper, Stiff e Radiais, com auxílio do software Qualigraf (FUNCEME, 2017). O mesmo software foi utilizado para classificação das águas quanto a salinidade, com base na quantidade de Sólidos Totais Dissolvidos (STD), regida pela Resolução 357/2005 do CONAMA.

Os diagramas hidroquímicos são ferramentas importantes para o entendimento do padrão hidroquímico das águas, sua relação com a litologia do aquífero e os processos hidrogeoquímicos envolvidos no referido padrão (Gastmans et al., 2005).

Para avaliação de erros analíticos foi utilizado o Balanço lônico, que segundo Cajazeiras (2007) é o primeiro passo para avaliar a qualidade da análise química de uma amostra. Em uma análise hidroquímica completa e correta, a soma dos cátions deve ser aproximadamente igual à soma dos ânions para uma mesma amostra.

Segundo Fenzl (1986) a qualidade da análise química de uma amostra pode estar relacionada aos fatores erro analítico ou de cálculo (erros acumulados em cada uma das determinações individuais); presença de íons menores (já que só são analisados os íons maiores) ou águas pouco mineralizadas, tais como águas de chuvas.

O Qualigraf realiza o cálculo do erro prático (Ep\%) baseado no balanço iônico por duas técnicas. Uma considera os valores da Condutividade Elétrica da água (C.E.) (Custódio \& Llamas, 1983); outra leva em consideração os valores dos somatórios dos cátions ou ânions (Logan, 1965). Os limites estão apresentados na Tabela 1. Abaixo dos intervalos de somatório dos cátions ou ânions e da condutividade elétrica têm-se o erro prático permitido.

Semelhante ao balanço iônico, o parâmetro STD (Sólidos Totais Dissolvidos) pode ser utilizado para aferir a acuracidade (exatidão) das análises. Recomendações da Eaton et al. (1998) estabelecem que a concentração medida dos STD deve ser maior que a calculada, porque um parâmetro que contribua significativamente pode não ter sido incluído no cálculo. Se o valor medido for menor que o calculado, o somatório dos íons maiores e o valor medido são suspeitos de erros e a amostra deve ser reanalisada. Se a 


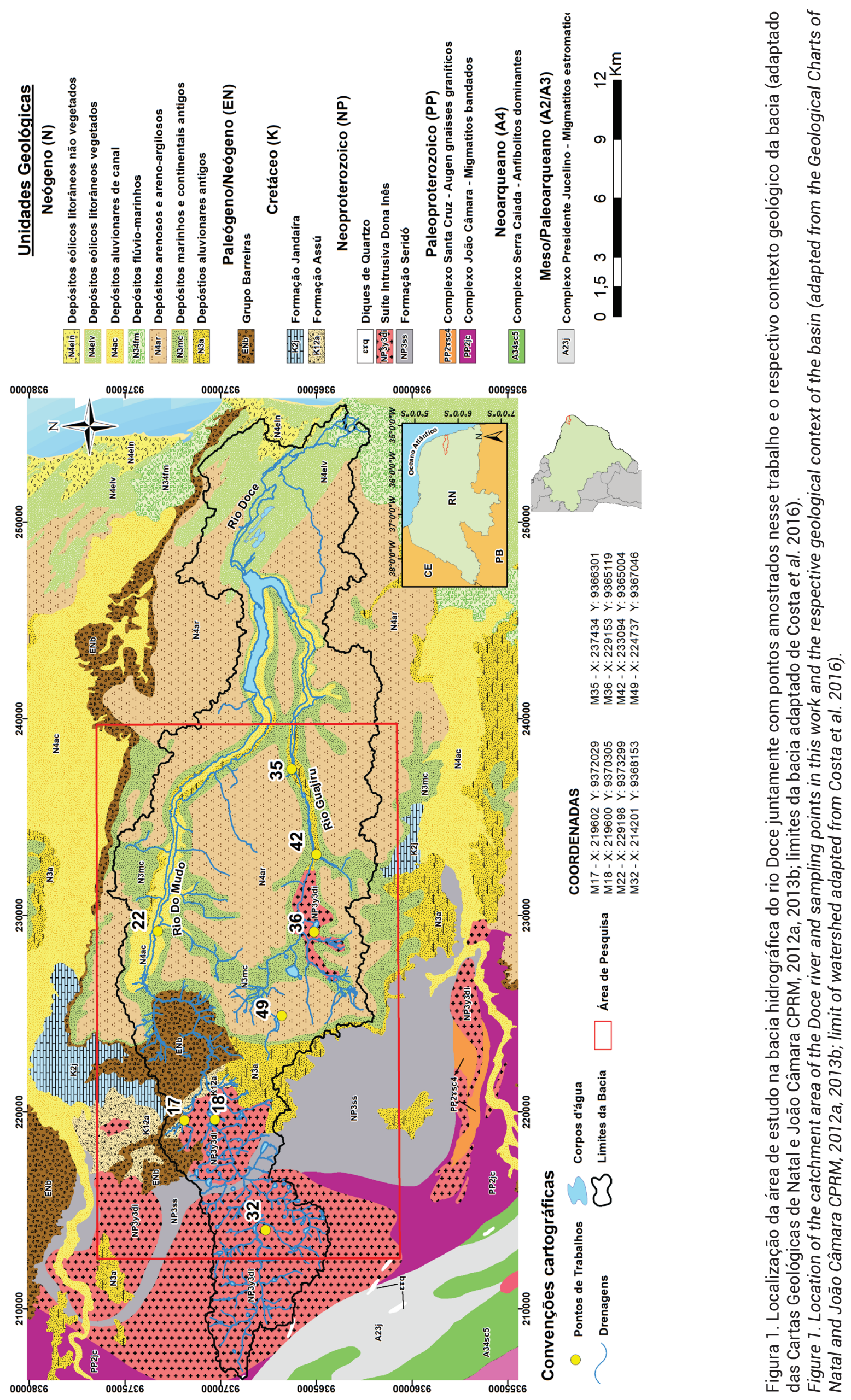


concentração medida dos sólidos for cerca de 20\% maior que a calculada, a soma dos íons menores é suspeita e os constituintes selecionados devem ser reanalisados. Uma razão aceitável é: $1<$ STD medido/STD calculado $<1,2$.

Os STD também foram utilizados (com informações do Qualigraf) para avaliar a salinidade das amostras de água, baseado na Resolução do Conselho Nacional de Meio Ambiente (CONAMA 357/2005) (Tab. 1); o software utiliza a referida Resolução e as quantidade dos STD nas amostras para qualificar as mesmas como doces, salobras ou salgadas, estabelecendo limites próprios ao programa.

Para sugerir possíveis ambientes de atuação das águas amostradas (interação águarocha) foi utilizada a razão iônica (Tab. 2). Os íons dissolvidos na água podem guardar uma relação genética com o terreno por onde essa percolou, ou percola. A química da água reflete a química do meio atravessado por ela. Estas relações são frequentemente designadas como índices, em que todos os valores são expressos em meq/L, sendo indicado por "r" (Hem, 1986).

\section{Resultados}

\subsection{Balanço iônico}

A Tabela 3 mostra o resultado do erro prático (\%Ep) calculado usando o Qualigraf, bem como as concentrações dos cátions e ânions em
meq/L. A coluna B.I.1 (Balanço lônico 1) mostra o erro prático para as amostras com base na condutividade elétrica; B.I.2 (Balanço Iônico 2) mostra o erro prático para cada amostra calculado com base no somatório dos cátions ou ânions.

A amostra M32 não se encaixou dentro do parâmetro da condutividade elétrica (ver colunas B.I.1 e Obs.). A C.E. dessa amostra apresenta valor de $22.170 \mu \mathrm{S} / \mathrm{cm}$, sendo o erro permitido para C.E. maiores que $2000 \mu \mathrm{S} / \mathrm{cm}$ menor ou igual a $4 \%$. O calculado para a amostra foi de $4,85 \%$. Isso não significa necessariamente que os resultados dessa amostra estão invalidados, mas pode indicar outros elementos menores, não incluídos nos cálculos, ou pode estar relacionado ao modo de análise empregado. Sendo a M32 a única destoante, assumiu-se que o erro pode estar relacionado a procedimentos de amostragem e/ou laboratoriais, ou ainda à presença de elementos menores não computados.

Seja baseado no método considerando os valores de C.E., ou nos valores dos somatórios dos cátions ou ânions, a maioria das amostras mostrou seus padrões de erro analítico normais, atendendo as especificações do Qualigraf.

\subsection{Razão STD medido/STD calculado}

A Tabela 4 mostra os resultados para condutividade elétrica e sólidos totais dissolvidos, além da classificação em relação à salinidade,

Tabela 1. Limites para avaliação do balanço iônico pelas metodologias de Custódio \& Llamas (1983) e Logan (1965). Também, classificação das águas com base no conteúdo de sólidos totais dissolvidos pela Resolução CONAMA $357 / 2005$ Table 1. Limits for evaluation of the ionic balance by the methodologies of Custódio \& Llamas (1983) and Logan (1965). Also, classification of waters based on the content of total dissolved solids, according to CONAMA Resolution 357/2005

\begin{tabular}{|c|c|c|c|c|c|c|c|}
\hline \multicolumn{8}{|c|}{ CONAMA (357/2005) } \\
\hline \multirow{2}{*}{$\begin{array}{c}\text { STD } \\
\text { (mg/L) }\end{array}$} & & Doce & \multicolumn{3}{|c|}{ Salobra } & \multicolumn{2}{|l|}{ Salgada } \\
\hline & & $0-500$ & & \multicolumn{2}{|l|}{$500-1500$} & \multicolumn{2}{|l|}{$>1500$} \\
\hline \multicolumn{8}{|c|}{ LOGAN (1965) } \\
\hline \multirow{2}{*}{$\begin{array}{c}\Sigma \text { Cátions } \\
\text { ou Ânions } \\
\text { Ep\% }\end{array}$} & $\Sigma<1$ & $1 \geq \Sigma<2$ & $2 \geq \Sigma<6$ & $6 \geq \Sigma<10$ & $10 \geq \Sigma<30$ & 30 & $>30$ \\
\hline & 15 & 10 & 6 & 4 & 3 & 2 & 1 \\
\hline \multicolumn{8}{|c|}{ CUSTÓDIO \& LLAMAS (1983) } \\
\hline \multirow{2}{*}{$\begin{array}{c}\text { C.E. } \\
(\mu \mathrm{S} / \mathrm{cm}) \\
\mathrm{Ep} \%\end{array}$} & $50 \geq \mathrm{CE}<200$ & $200 \geq C E<500$ & $500 \geq \mathrm{CE}<2000$ & 2.000 & $>2.000$ & $50 \geq \mathrm{CE}<200$ & $\begin{array}{c}200 \geq \\
\mathrm{CE}< \\
500\end{array}$ \\
\hline & 30 & 10 & 8 & 4 & $<4$ & 30 & 10 \\
\hline
\end{tabular}

C.E. - Condutividade elétrica; STD - Sólidos Totais Dissolvidos; Ep\% - erro prático permitido 
Tabela 2. Razões iônicas e seus valores teóricos e respectivos significados com a relação genética (adaptado de Hem, 1986).

Table 2. Ionic ratios and their theoretical values and respective meanings with genetic relation (adapted from Hem, 1986).

\begin{tabular}{|c|c|c|}
\hline Razão lônica & Variações Teóricas & Significado \\
\hline \multirow{5}{*}{$\mathrm{rMg}^{+2} / \mathrm{rCa}^{+2}$} & $0,25-0,33$ & - Água de circulação em rocha de composição granítica \\
\hline & $0,33-1,5$ & - Águas continentais \\
\hline & $>0,9$ & $\begin{array}{l}\text { - Contato com água do mar ou fluxo através de rocha básica; } \\
\text { possível influência de terrenos dolomíticos }\end{array}$ \\
\hline & $>1$ & - Relação com litotipos ricos em silicatos magnesianos \\
\hline & \pm 5 & - Água do mar \\
\hline $\mathrm{rCa}^{+2} / \mathrm{rMg}^{+2}$ & $>1$ & - Indicação de intrusão marinha \\
\hline \multirow{3}{*}{$\mathrm{rK}^{+} / \mathrm{rNa}^{+}$} & $\begin{array}{l}0,02-0,025 \\
0,09-0,6\end{array}$ & $\begin{array}{l}\text { - Água do mar } \\
\text { - Água de circulação em rocha granítica }\end{array}$ \\
\hline & $0,004-0,28$ & - Água doce \\
\hline & $<0,0876$ & - Água do mar \\
\hline $\mathrm{rNa}^{+} / \mathrm{rCl}^{-}$ & $\begin{array}{l}<0,7 \\
>0,7\end{array}$ & $\begin{array}{l}\text { - Substituição de } \mathrm{Na}^{+} \text {por } \mathrm{Ca}^{+} \text {e } \mathrm{Mg}^{+2} \\
\text { - Precipitação de sais de } \mathrm{Na}^{+} \\
\text {- Fluxo através de rochas cristalinas ou vulcânicas }\end{array}$ \\
\hline $\mathrm{rCl} / / \mathrm{rHCO}_{3}$ & $\begin{array}{l}0,5 \\
0,1-0,5 \\
20-50\end{array}$ & $\begin{array}{l}\text { - Fluxo normal para rochas cristalinas } \\
\text { - Águas continentais } \\
\text { - Água do mar }\end{array}$ \\
\hline
\end{tabular}

Tabela 3. Resultados para os erros práticos baseados no somatório dos cátions ou ânions e na condutividade elétrica (CE) obtidos através do software Qualigraf. A amostra M32 apresentou infração aos critérios estabelecidos para o balanço iônico.

Table 3. Results for the practical errors based on the sum of the cations or anions and the electrical conductivity (CE) obtained through Qualigraf software. Sample M32 was in violation of the established criteria for the ionic balance.

\begin{tabular}{|c|c|c|c|c|c|c|c|c|c|c|c|c|}
\hline $\mathrm{AM}$ & $\mathrm{Na}+\mathrm{K}$ & $\mathrm{Ca}$ & $\mathrm{Mg}$ & $\mathrm{Cl}$ & $\begin{array}{l}\mathrm{CO}_{3}+ \\
\mathrm{HCO}_{3} \\
\end{array}$ & $\mathrm{SO}_{4}$ & CE & $\begin{array}{c}\Sigma \\
\text { Cátions }\end{array}$ & $\begin{array}{c}\Sigma \\
\text { Ânions } \\
\end{array}$ & $\begin{array}{l}\text { B.I.1 } \\
\text { \%Ep }\end{array}$ & $\begin{array}{l}\text { B.I.2 } \\
\% \text { Ep }\end{array}$ & Obs. \\
\hline M17 & 239,90 & 16,14 & 89,89 & 320,01 & 22,07 & 752,69 & $27.620,00$ & 345,93 & 336,04 & 2,90 & 1,45 & OK \\
\hline M18 & 78,51 & 3,02 & 27,33 & 102,73 & 105,34 & 46,24 & $10.673,00$ & 108,86 & 105,52 & 3,12 & 1,56 & OK \\
\hline M22 & 3,51 & 2,16 & 2,58 & 5,14 & 166,75 & 24,20 & 930,60 & 8,25 & 8,37 & 1,52 & 0,76 & OK \\
\hline M32 & 212,37 & 10,93 & 77,42 & 272,74 & 72,34 & 603,04 & $22.170,00$ & 300,72 & 286,48 & 4,85 & 2,43 & B.I. 1 e B.I. 2 \\
\hline M35 & 0,47 & 0,01 & 0,11 & 0,36 & 2,45 & 5,42 & 71,67 & 0,59 & 0,52 & 13,37 & 6,68 & OK \\
\hline M36 & 4,72 & 0,57 & 1,16 & 4,91 & 114,03 & 6,87 & 826,50 & 6,45 & 6,92 & 6,99 & 3,49 & OK \\
\hline M42 & 11,13 & 1,61 & 4,31 & 14,09 & 136,09 & 7,29 & $1.834,40$ & 17,05 & 16,47 & 3,47 & 1,73 & OK \\
\hline M49 & 4,53 & 0,11 & 1,32 & 4,73 & 74,79 & 19,40 & 789,50 & 5,96 & 6,36 & 6,42 & 3,21 & OK \\
\hline
\end{tabular}

As concentrações dos elementos e os somatórios são dados em meq/L; CE - Condutividade Elétrica em $\mu \mathrm{S} / \mathrm{cm}$; Ep - Erro prático; B.I.1 - Balanço Iônico com base na CE; B.I.2 - Balanço Iônico com base no somatório de cátions ou ânions. 
usando STD medidos, e as razões STD Medidos/ STD estimadas pelo Qualigraf. Os valores em negrito evidenciam amostras que não atendem ao intervalo proposto $(1,0<$ razão $<1,2)$.

Os valores em negrito na última coluna da Tabela 4 mostram duas violações ao intervalo recomendado para a razão STD medido/STD calculado, sendo as amostras M32 e M49 as que apresentaram erro. O valor de 1,29 para a amostra M32 pode indicar que a soma dos íons menores está causando um erro analítico. 0 valor de 0,98 para a amostra M49, indica que pode haver erro na soma dos íons maiores ou no valor medido para o STD.

Como a razão observada para a maioria das amostras está adequada ao intervalo proposto, e as razões que não estão adequadas não divergem muito do mesmo intervalo, aceitouse os resultados como válidos no âmbito do trabalho.

\subsection{Sólidos totais dissolvidos (STD)}

Com base nos resultados obtidos no software Qualigraf, que por sua vez se baseia nos parâmetros da Resolução 357/2005 do CONAMA e em limites estipulados pelo próprio programa, é possível ver na coluna "Observações" da Tabela 4 que três (3) das oito amostras apresentaram STD medido maior que $1500 \mathrm{mg} / \mathrm{L}$, sendo classificadas como salgadas. Quatro das oito amostras apresentaram STD entre 500mg/L e $1500 \mathrm{mg} / \mathrm{L}$, sendo definidas como salobras. Uma amostra apresentou STD entre Omg/L e $500 \mathrm{mg} / \mathrm{L}$, sendo definida como uma água doce.

\subsection{Razões iônicas}

A composição química das águas pode ter alguma relação com a composição dos ambientes e materiais através dos quais estas percolam. As razões iônicas auxiliam na caracterização dessa relação de ambiente com a água.

A Tabela 5 apresenta em suas colunas as razões iônicas para cada amostra coletada. 0 símbolo "r" indica que as concentrações dos íons estão dadas em meq/L. As interpretações dos resultados foram feitas com base nos valores para razões iônicas manifestados na Tabela 2.
As razões para a amostra $\mathrm{M} 17$ foram: $\mathrm{rMg}^{+2} /$ $\mathrm{rCa}^{+2}=5,64$, equivalente a água do mar; $\mathrm{rCa}^{+2} /$ $\mathrm{rMg}^{+2}=0,18$, não indicando intrusão marinha; $\mathrm{rK}^{+} / \mathrm{rNa}^{+}=0,03$, correspondendo a água doce; $\mathrm{rNa}^{+} / \mathrm{rCl}^{-}=0,73$, apontando um fluxo através de rochas cristalinas ou vulcânicas; e $\mathrm{rCl}^{-} / \mathrm{rHCO}_{3}^{-}=$ 887,62 , muito maior do que o correspondente a água do mar.

As razões para a amostra M18 foram: $\mathrm{rMg}^{+2} / \mathrm{rCa}^{+2}=9,17$, indicando relação com litotipos ricos em silicatos magnesianos; $\mathrm{rCa}^{+2} /$ $\mathrm{rMg}^{+2}=0,11$, não indicando intrusão marinha; $\mathrm{rK}^{+} / \mathrm{rNa}^{+}=0,03$, correspondendo a água doce; $\mathrm{rNa}^{+} / \mathrm{rCl}^{-}=0,74$, apontando um fluxo através de rochas cristalinas ou vulcânicas; e $\mathrm{rCl}^{-} / \mathrm{rHCO}_{3}^{-}=$ 69,31, equivalente a água do mar.

As razões para a amostra M22 foram: $\mathrm{rMg}+2 / \mathrm{rCa}+2=1,21$, equivalente $a$ águas continentais; $\mathrm{rCa}^{+2} / \mathrm{rMg}^{+2}=0,83$, não indicando intrusão marinha; $r \mathrm{~K}^{+} / \mathrm{rNa}^{+}=0,04$, correspondendo a água doce; $\mathrm{rNa}^{+} / \mathrm{rCl}^{-}=0,66$, indica possível precipitação de sais de $\mathrm{Na}^{+}$; e $\mathrm{rCl}^{-} / \mathrm{rHCO}_{3}^{-}=1,96$, valor aproximado para águas continentais.

As razões para a amostra M32 foram: $\mathrm{rMg}^{+2} / \mathrm{rCa}^{+2}=7,17$, indicando relação com litotipos ricos em silicatos magnesianos; $\mathrm{rCa}^{+2} /$ $\mathrm{rMg}^{+2}=0,14$, não indicando intrusão marinha; $\mathrm{rK}+/ \mathrm{rNa}+=0,03$, correspondendo a água doce; $\mathrm{rNa}^{+} / \mathrm{rCl}^{-}=0,76$, apontando um fluxo através de rochas cristalinas ou vulcânicas; e $\mathrm{rCl}^{-} / \mathrm{rHCO}_{3}{ }^{-}=$ 236,82, muito maior do que o correspondente a água do mar.

As razões para a amostra M35 foram: $\mathrm{rMg}^{+2} / \mathrm{rCa}^{+2}=11,60$, indicando relação com litotipos ricos em silicatos magnesianos; $\mathrm{rCa}^{+2} /$ $\mathrm{rMg}^{+2}=0,09$, não indicando intrusão marinha; $\mathrm{rK}^{+} / \mathrm{rNa}^{+}=0,02$, semelhante a água do mar; $\mathrm{rNa}^{+}$/ $\mathrm{rCl}^{-}=1,26$, apontando um fluxo através de rochas cristalinas ou vulcânicas; e $\mathrm{rCl}^{-} / \mathrm{rHCO}_{3}^{-}=9,08$, próximo a valores de águas continentais.

As razões para a amostra M36 foram: $\mathrm{rMg}^{+2} / \mathrm{rCa}^{+2}=2,06$, indicando relação com litotipos ricos em silicatos magnesianos; $\mathrm{rCa}^{+2} /$ $\mathrm{rMg}^{+2}=0,49$, não indicando intrusão marinha; $\mathrm{rK}^{+} / \mathrm{rNa}^{+}=0,09$, correspondendo a água de circulação em rocha com composição granítica; $\mathrm{rNa}^{+} / \mathrm{rCl}^{-}=0,88$, apontando um fluxo através de rochas cristalinas ou vulcânicas; e $\mathrm{rCl}^{-} / \mathrm{rHCO}_{3}^{-}=$ 2,72 , próximo a valores de águas continentais. 
Tabela 4 - Resultados de condutividade elétrica (CE) e sólidos totais dissolvidos (STD). Na penúltima coluna: classificação em relação a salinidade usando STD medidos. Última coluna: razões para STD Medido/STD estimado. Os valores em negrito evidenciam as amostras que não atendem ao intervalo proposto.

Table 4 - Results of electrical conductivity (EC) and total dissolved solids (TDS). In the penultimate column: classification in relation to salinity using measured TDS. Last column: Ratio for Measured TDS / Estimated TDS. The values in bold show the samples that do not meet the proposed range.

\begin{tabular}{cccclc}
\hline Amostra & C.E. & $\begin{array}{c}\text { STD } \\
\text { estimado } \\
\mathbf{m} \text { g/L) }\end{array}$ & $\begin{array}{c}\text { STD } \\
\text { medido } \\
(\mathbf{m g} / \mathbf{L})\end{array}$ & Observações & $\begin{array}{c}\text { Razão STD Medido/ } \\
\text { Estimado }\end{array}$ \\
\hline M17 & $27.620,00$ & $17.953,00$ & $20.721,00$ & Água Salgada & 1,15 \\
M18 & $10.673,00$ & $6.937,50$ & $7.170,00$ & Água Salgada & 1,03 \\
M22 & 930,6 & 604,9 & 635 & Água Salobra & 1,04 \\
M32 & $22.170,00$ & $14.410,50$ & $18.663,00$ & Água Salgada & 1,29 \\
M35 & 71,67 & 46,6 & 48,73 & Água Doce & 1,04 \\
M36 & 826,5 & 537,2 & 575 & Água Salobra & 1,07 \\
M42 & $1.834,40$ & $1.192,40$ & $1.204,00$ & Água Salobra & 1,009 \\
M49 & 789,5 & 513,2 & 504 & Água Salobra & $\mathbf{0 , 9 8}$ \\
\hline
\end{tabular}

As razões para a amostra $\mathrm{M} 42$ foram: $\mathrm{rMg}^{+2} /$ $\mathrm{rCa}^{+2}=2,71$, indicando relação com litotipos ricos em silicatos magnesianos; $\mathrm{rCa}^{+2} / \mathrm{rMg}^{+2}=0,37$, não indicando intrusão marinha; $\mathrm{rK}^{+} / \mathrm{rNa}^{+}=0,05$, correspondendo a água aparentemente doce; $\mathrm{rNa}^{+} / \mathrm{rCl}^{-}=0,75$, apontando um fluxo através de rochas cristalinas ou vulcânicas; e $\mathrm{rCl}^{-} / \mathrm{rHCO}_{3}{ }^{-}=$ 6,61, próximo a valores de águas continentais.

As razões para a amostra $\mathrm{M} 49$ foram: $\mathrm{rMg}^{+2} /$ $\mathrm{rCa}^{+2}=11,63$, indicando relação com litotipos ricos em silicatos magnesianos; $\mathrm{rCa}^{+2} / \mathrm{rMg}^{+2}=$ 0,09, não indicando intrusão marinha; $\mathrm{rK}^{+} / \mathrm{rNa}^{+}$ = 0,06, correspondendo a água aparentemente doce; $\mathrm{rNa}^{+} / \mathrm{rCl}^{-}=0,90$, apontando um fluxo através de rochas cristalinas ou vulcânicas; e $\mathrm{rCl}^{-} / \mathrm{rHCO}_{3}$ $=4,11$, próximo a valores de águas continentais.

Observa-se que o nível de interação rochaágua é expressivo, visto que boa parte das razões iônicas mostram que as águas tiveram alguma percolação e contato com rochas graníticas ou vulcânicas como as que são observadas na região. As razões obtidas que são equivalentes a águas marinhas ou intrusão salina (para $\mathrm{Mg}^{+2} /$ $\mathrm{rCa}^{+2}: \mathrm{M} 17 ; \mathrm{rK}^{+} / \mathrm{rNa}^{+}: \mathrm{M} 35$; e para $\mathrm{rl}^{-} / \mathrm{rHCO}_{3}: \mathrm{M} 17$, M18 e M32) mostram a elevada salinidade nessas amostras provavelmente pela falta de renovação sazonal/temporal das águas onde foram feitas as coletas, em função da concentração progressiva de sais motivada pela evaporação.

\subsection{Diagramas hidroquímicos}

\subsubsection{Diagrama de Piper}

Os resultados para as oito amostras foram plotados em um diagrama de Piper. As concentrações de cátions e de ânions são estimadas em percentagem e plotadas nos seus respectivos diagramas triangulares abaixo do losango de classificação principal. No diagrama dos cátions sete amostras estão no campo das águas sódicas; a exceção é a M22, classificada como cloretada mista. No diagrama dos ânions todas as amostras estão no campo das águas cloretadas (Fig. 2). Com base na projeção do diagrama classificou-se sete amostras como águas cloretadas sódicas. Dentre as águas cloretadas sódicas, três amostras (M17, M18 e M32) formam um agrupamento, evidenciado pela proximidade dos pontos plotados. Os demais pontos apresentam-se mais distribuídos em termos de composição química. O ponto mais destoante do contexto das amostras é o representativo da amostra M22 (roxo).

Os agrupamentos ocorrem devido a interação das águas amostradas com os diferentes tipos de rochas existentes na área de estudo. O grupo formado (M17, M18 e M32) está relacionado às rochas graníticas que fazem parte 
Tabela 5. Resultados para as razões iônicas calculadas para cada amostra coletada. Significados adaptados de Hem (1986).

Table 5. Results for the ionic ratios calculated for each sample collected. Signification adapted from Hem (1986).

\begin{tabular}{|c|c|c|c|c|c|c|}
\hline Amostras & $\mathrm{rMg}^{+2} / \mathrm{rCa}^{+2}$ & $\mathrm{rCa}^{+2} / \mathrm{rMg}^{+2}$ & $\mathrm{rK}^{+} / \mathrm{rNa}^{+}$ & $\mathrm{rNa}^{+} / \mathrm{rCl}^{-}$ & $\mathrm{rCl} / \mathrm{rHCO}_{3}^{-}$ & Significados \\
\hline M17 & 5,64 & 0,18 & 0,03 & 0,73 & 887,62 & $\mathrm{rMg}^{+2} / \mathrm{rCa}^{+2}-\mathrm{M} 17$ águas marinhas; M22 águas \\
\hline M18 & 9,17 & 0,11 & 0,03 & 0,74 & 69,31 & continentais; demais, relação das águas com \\
\hline M22 & 1,21 & 0,83 & 0,04 & 0,66 & 1,96 & litotipos ricos em silicatos magnesianos. \\
\hline M32 & 7,17 & 0,14 & 0,03 & 0,76 & 236,82 & $\mathrm{rCa}^{+2} / \mathrm{rMg}^{+2}$ - valores mostram não intrusão marinha. \\
\hline M35 & 11,60 & 0,09 & 0,02 & 1,26 & 9,08 & $\mathrm{rK}^{+} / \mathrm{rNa}^{+}$- M35 água do mar; M36 água em rochas \\
\hline M36 & 2,06 & 0,49 & 0,09 & 0,88 & 2,72 & graníticas; demais, águas doces. \\
\hline M42 & 2,71 & 0,37 & 0,05 & 0,75 & 6,61 & $\mathrm{rNa}^{+} / \mathrm{rCl}^{-}$- com exceção da M22, todas apontam \\
\hline M49 & 11,63 & 0,09 & 0,06 & 0,90 & 4,11 & para fluxo por rochas cristalinas ou vulcânicas. \\
\hline
\end{tabular}

$\mathrm{r}$ - simbologia indicando que para o cálculo das razões iônicas foram utilizadas as concentrações dos elementos em miliequivalentes por litro (meq/L).

do embasamento cristalino. As demais amostras estão em contextos geológicos mais variados, como sedimentos aluvionares e na Formação Barreiras.

\subsubsection{Diagramas de Stiff}

Os resultados nos diagramas de Stiff apontam similaridades entre as figuras geométricas para as amostras M17, M18 e M32, o que indica um agrupamento que se encontra delimitado na Figura 3. As concentrações de $\mathrm{Na}^{+}$e $\mathrm{Cl}^{-}$, no eixo horizontal, se apresentam bem mais elevadas que os demais íons. Isso gera as representações geométricas observadas, largas no eixo superior, apertadas no eixo intermediário e estreitas no eixo inferior (Fig. 3).

Para as amostras M36, M42 e M49 também é observado um padrão de similaridade entre as figuras geométricas geradas, razão pela qual estão agrupadas na figura 3. Diferentemente das amostras citadas anteriormente, essas mostram um enriquecimento no eixo horizontal intermediário $\left(\mathrm{Ca}^{+2}\right.$ e $\left.\mathrm{HCO}_{3}^{-}\right)$, fazendo com que a figura geométrica apresente uma dimensão maior nesse ponto (Fig. 3).

As figuras geométricas representativas das amostras M22 e M35 se mostraram relativamente diferentes das demais amostras. o caso mais destoante é da amostra M22, em que a representação mostra certo equilíbrio entre os cátions e ânions. A amostra M35 mostra uma predominância de $\mathrm{Na}^{+}$em sua composição como pode ser observado no diagrama de Stiff (Fig. 3).

\subsubsection{Diagramas Radiais}

A Figura 4 apresenta as geometrias dos diagramas radiais para todas as amostras; acerca das amostras M17, M18 e M32 pode-se inferir a formação de um grupo que está demarcado na figura, devido a semelhanças entre os diagramas. Essas amostras apresentam nos diagramas radiais uma predominância de concentração nos eixos que correspondem ao $\mathrm{Cl}^{-}, \mathrm{Na}^{+}$e $\mathrm{Mg}^{+2}$, sendo mais cloretadas que magnesianas ou sódicas.

Os diagramas radiais das amostras M36, M42 e M49 indicam um possível outro grupo formado, que se encontra delimitado na figura 4; as amostras apresentam concentrações nos eixos $\mathrm{CO}_{3}^{-2}+\mathrm{HCO}_{3}^{-}, \mathrm{Cl}^{-}, \mathrm{Na}^{+}$e $\mathrm{Mg}^{+2}$. É possível observar o aparecimento ou enriquecimento do carbonato e bicarbonato em relação às amostras anteriormente mencionadas, causando a diferenciação desse grupo em relação ao antecedente.

A M22 se mostra atípica no contexto das demais analisadas; apresenta concentração relativamente homogênea em todos os elementos com exceção do $\mathrm{SO}_{4}^{-2}$, observado em baixa quantidade. A amostra M35 também não aparenta ter semelhanças químicas expressivas com as demais amostras. Mostra um enriquecimento de concentração nos eixos do $\mathrm{Cl}^{-}$ e $\mathrm{Mg}^{+2}$, semelhante ao primeiro grupo, mas um enriquecimento de $\mathrm{SO}_{4}{ }^{-2}$, não observado nem no primeiro e nem no segundo grupo de amostras, diferenciando esta das demais. 


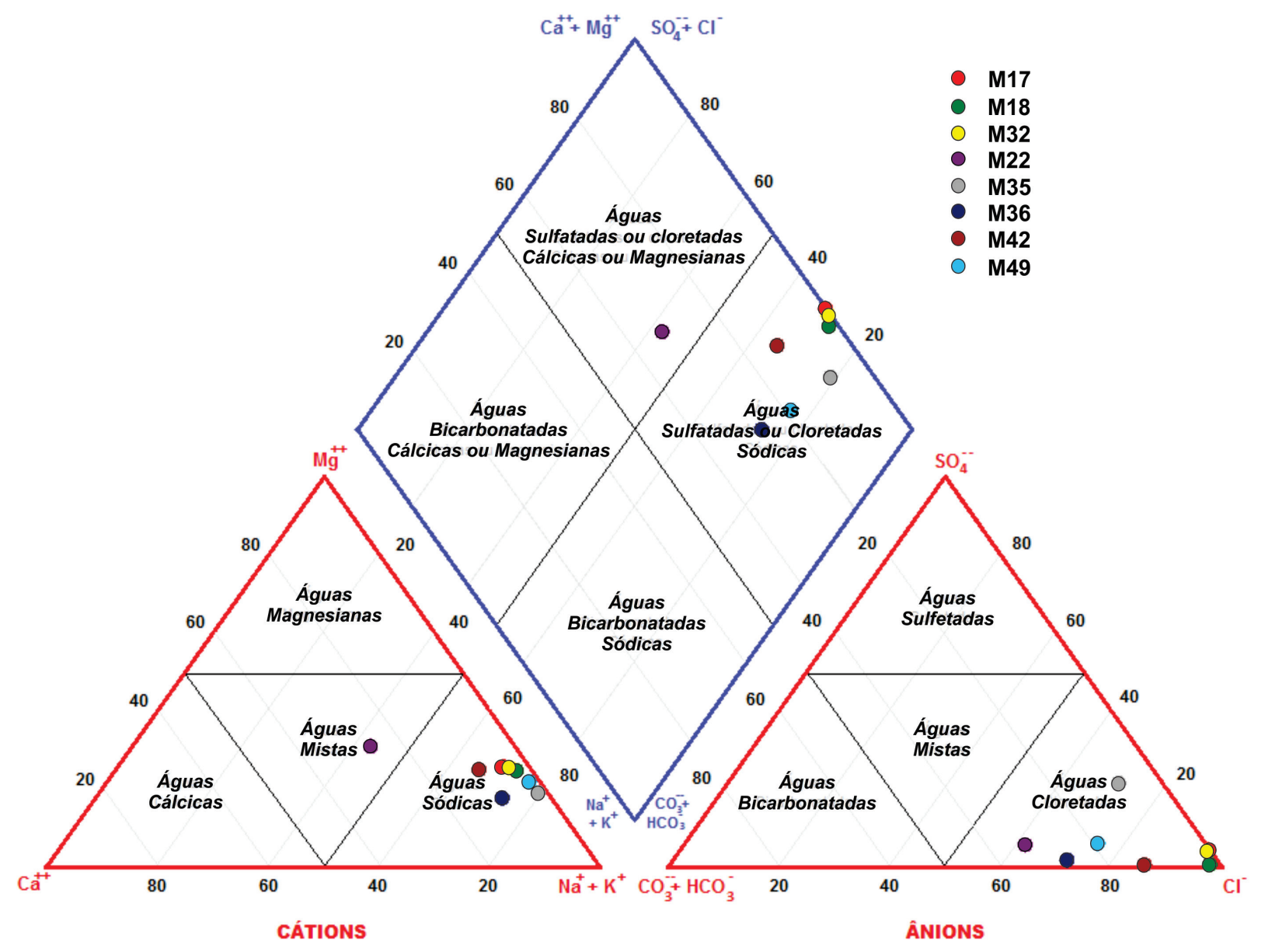

Figura 2. Diagrama de Piper com amostras plotadas. No triângulo correspondente aos cátions ver agrupamento da maioria das amostras no campo de águas sódicas. No triângulo correspondente aos ânions ver as amostras no campo das águas cloretadas. A projeção desses resultados no diagrama superior classifica as águas como cloretadas sódicas. Figure 2. Piper diagram with plotted samples. In the triangle corresponding to the cations see grouping of most of the samples in the field of sodium waters. In the triangle corresponding to the anions see the samples in the field of chlorine type water. The projection of these results in the upper diagram classifies the waters as sodium-chlorine type.

O diagrama de Piper classificou as amostras majoritariamente como cloretadas sódicas. Os diagramas de Stiff e os Radiais permitem ver uma correlação espacial entre as amostras. As amostras do alto curso do rio do Mudo possuem semelhanças quanto aos diagramas, bem como as do rio Guajiru. Há uma relação genética entre elas e a região de nascente das respectivas subbacias, bem como com a geologia.

\section{Discussão dos resultados}

Os métodos gráficos foram utilizados nesse trabalho para se avaliar a existência, ou não, de correlação entre a composição química das águas e os tipos litológicos pelos quais essas águas circulam.
Considerando os resultados, as maiores concentrações dos elementos e espécies químicas estudados se apresentam na subbacia do rio do Mudo, especificamente nos pontos de amostragem M17, M18 e M32. Esses pontos guardam relações de características de ocorrência similares entre si. Todos ocorrem em locais de represamentos de água na forma de barramentos, sendo uma característica comum para o alto curso da bacia; também não há aparente recarga/renovação das suas águas ou contribuição para as mesmas por parte do aquífero Barreiras, pois no setor ocidental e de nascentes da área, o Barreiras é pouco espesso e insaturado, os aquíferos Açu e Jandaíra têm níveis mais profundos sem conexão com a drenagem superficial, e os terrenos são 


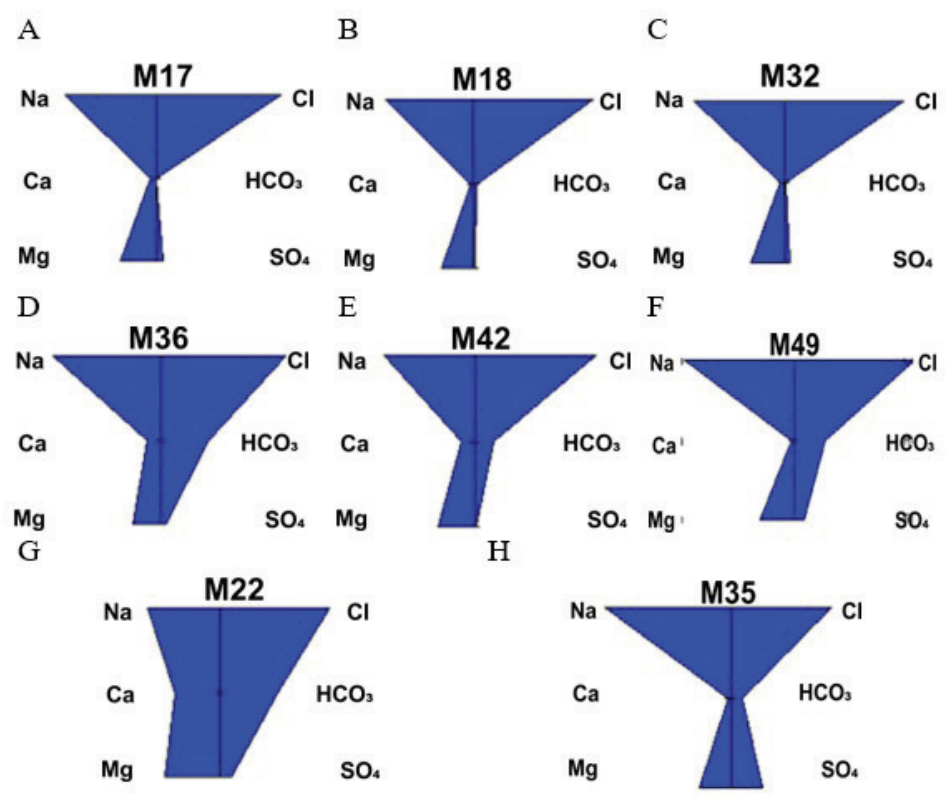

Figura 3. Diagramas de Stiff para as amostras. A) Diagrama para o ponto M17; B) Diagrama para o M18; C) Diagrama para o M32; D) Diagrama para o M36; E) Diagrama para M42; F) Diagrama para o M49; G) Diagrama para o M22; H) Diagrama para o M35. São observadas semelhanças nas geometrias dos diagramas de algumas das amostras. É possível depreender a existência de dois grupos representativos: alto curso do rio Do Mudo (A a C), e alto curso do rio Guajiru (D a F).

Figure 3. Stiff diagrams for the samples. A) Diagram for point M17; B) Diagram for M18; C) Diagram for M32; D) Diagram for the M36; E) Diagram for M42; F) Diagram for M49; G) Diagram for M22; H) Diagram for the M35. Similarities are observed in the geometries of the diagrams of some of the samples. It is possible to deduce the existence of two representative groups: upper course of the Do Mudo river (A to $C$ ), and upper course of the Guajiru river (D to $F$ ).

A

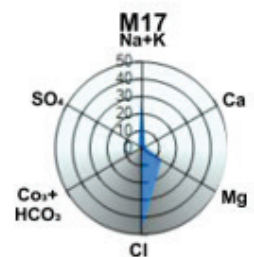

D

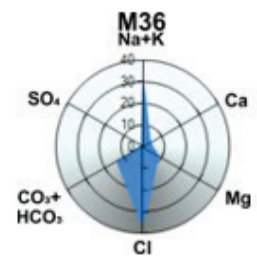

G

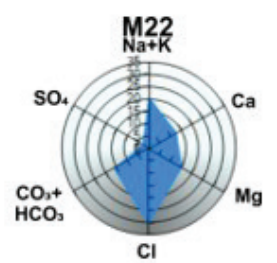

B

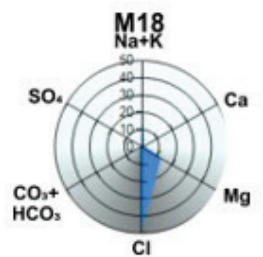

$\mathrm{E}$

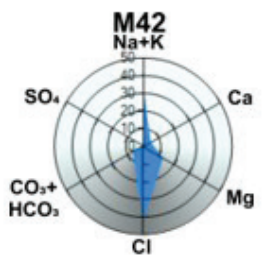

$\mathrm{H}$
$\mathrm{C}$

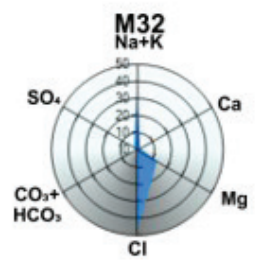

$\mathrm{F}$
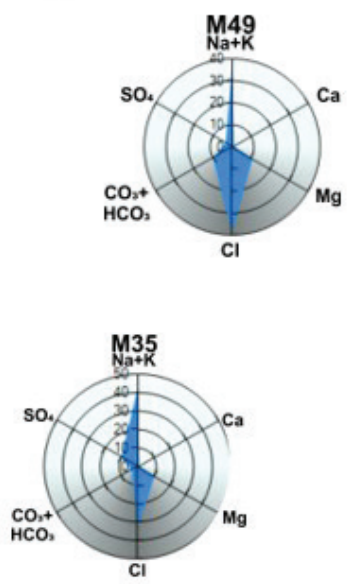

Figura 4. Diagramas Radiais para as amostras. A) Diagrama para o ponto M17; B) Diagrama para o M18; C) Diagrama para o M32; D) Diagrama para o M36; E) Diagrama para M42; F) Diagrama para o M49; G) Diagrama para o M22; H) Diagrama para o M35. Pelos diagramas é possível notar uma tendência a agrupamento similar aos observados nos diagramas de Stiff (Fig. 3), ou seja, a existência de dois grupos representativos do alto curso de cada bacia.

Figure 4. Radial diagrams for the samples. A) Diagram for point M17; B) Diagram for M18; C) Diagram for M32; D) Diagram for the M36; E) Diagram for M42; F) Diagram for M49; G) Diagram for M22; H) Diagram for the M35. By the diagrams it is possible to notice a tendency to similar groupings to those observed in the Stiff diagrams (Fig. 3), that is, the existence of two representative groups of the upper course of each sub basin. 
predominantemente de rochas cristalinas granito-gnáissicas que compõem o aquífero Fissural/Cristalino, o qual também não mostra relação com a drenagem superficial (não há efluência de águas subterrâneas).

Segundo dados climatológicos da EMPARN o Estado do RN vem enfrentando irregularidade nas chuvas ao longo dos últimos sete anos; águas estagnadas por muito tempo, sem a contribuição ou renovação delas por chuva ou aquífero, apresentam tendência em concentrar íons pela evaporação. Com a perda de água por evaporação e demais usos, a tendência é que as águas mostrem aumento progressivo da concentração salina.

Em investigação sobre a hidrogeoquímica das águas da bacia sedimentar potiguar, Stein (2013) argumenta que no domínio semiárido os sais se acumulam progressivamente no solo pelo efeito da alta evaporação e evapotranspiração, e dos baixos índices de precipitação pluviométrica. Esses elementos podem ser carreados para reservatórios ou aquíferos, aumentando a salinidade deles. Esse fato revela que o aumento da mineralização das águas não está ligado somente a interação água-rocha, mas a outros fatores também.

Taherietal.(2017)estudandocontaminação de água por arsênio em regiões semiáridas do Irã argumentam que para a região, além da interação água-rocha, a evaporação também define a química das águas estudadas. No Paquistão Qaisar et al. (2018) definiram a atuação da evaporação como influente na química das águas superficiais. Também observaram que a presença de elevadas concentrações de STD está relacionada a condição árida à semiárida da região e à interferência antropogênica. Zhang et al. (2019) relacionaram a salinização do Lago Qingtu na china com o fenômeno da forte evaporação da água superficial e consequente precipitação de sais no fundo do reservatório. A exemplo dos citados, estudos em áreas semiáridas de outros países (Shanyengana et al., 2004; Jiang et al., 2015) também têm mostrado que a alta taxa de evaporação e radiação solar, associados a baixas taxas de precipitação, levam ao aumento na concentração de certos íons, elevando a salinidade.
Medeiros (2004) mostra que a salinidade, em microbacia na região Central do RN, não é proveniente tão somente da interação águarocha, mas atrela a evaporação como processo significativo de altas taxas de STD, ocorrendo quando as águas ainda estão na superfície.

Para uma lagoa no litoral Oriental do RN, Melo et al. (2005) argumentam que a alta salinidade encontrada em pontos do aquífero Barreiras pode estar relacionada a fatores geológicos ou climáticos típicos de semiárido, visto a área do trabalho estar em região de transição para esse domínio; a área desse trabalho se encaixa nessas características de transição para o semiárido, apresentando elevada salinidade nos pontos M17, M18 e M32 que, além da localização sobre rochas cristalinas, encontram-se a oeste da bacia, onde os índices de precipitação pluviométrica variam de 600 a 900 mm/ano (EMPARN), com no máximo dez dias de precipitação mensal entre maio e julho.

Essas sazonalidades climáticas, além de ocorrerem em intervalos anuais, também manifestam alterações nos períodos de chuva ou estiagem. Leprun (1983) observou que, em relação à época do ano, há variação na composição das águas dos açudes, da estação chuvosa para a seca, havendo aumento nas concentrações, em valores percentuais de $\mathrm{Na}^{+} \mathrm{e}$ $\mathrm{Cl}^{-}$, enquanto o $\mathrm{Ca}^{2+}, \mathrm{K}^{+}, \mathrm{SO}_{4}{ }^{2-}$ e, principalmente, o $\mathrm{HCO}_{3}{ }^{-}$, diminuíram relativamente na estação seca. O que se observa na área estudada é um comportamento similar; as amostragens foram feitas em início de período seco, após sete anos de seca; as águas apresentaram elevadas concentrações de $\mathrm{Na}^{+}$e $\mathrm{Cl}$-, em detrimento dos outros íons.

O relevo também pode ser fator importante para concentração de elementos na água. Custódio \& Llamas (1983) argumentam que áreas de planícies, regionais ou locais, pouco profundas, propiciam a pouca mobilidade das águas devido às condições de baixa energia potencial do terreno, permanecendo por muito tempo no mesmo local e submetidas à evaporação, favorecendo o aumento da salinidade. Ma et al. (2019), investigando bacia hidrográfica no noroeste da China, afirmam que as mudanças no escoamento afetam as 
características da química da água. Os autores sugerem que as concentrações mais altas de elementos podem se relacionar com períodos de baixo fluxo do rio, ou seja, infere-se que em águas lentas ou estagnadas a tendência é de alta nas concentrações; fato semelhante é observado na área estudada.

Costa et al. (2006) usam esse argumento para atribuir o aumento da salinidade nos aquíferos sob influência do cristalino na região Agreste potiguar, aos terrenos de relevos planos e pouco movimentados. As regiões Centro-Norte e Leste do RN são planas, com pouca variação topográfica; dessa forma apresentam aquíferos de alta salinidade se comparados às regiões Sul e Oeste do estado (SILVA, 2003a, 2003b).

Com pouca renovação das águas acumuladas superficialmente ocorre também o aumento do tempo de interação entre elas e o substrato rochoso. O que se percebe então, através dos diagramas hidroquímicos e das análises químicas, é que a assinatura química dessas águas pode estar relacionada com a composição química e mineralógica das rochas subjacentes com as quais estão em contato e/ ou através das que percolam, bem como com a questão climática específica da área de estudo.

Como visto anteriormente os sais dissolvidos nas águas amostradas podem ser oriundos de diferentes fontes, e decorrentes de diversos processos. O diagrama de Gibbs (1970) foi proposto como ferramenta para estudar a química das águas superficiais que é controlada por três processos: intemperismo, ou interação rocha/água; precipitação atmosférica; e evaporação/cristalização. Ma et al. (2019) argumentam que pode haver influência da geologia regional nas condições hidroquímicas e hidrológicas da bacia hidrográfica. Os autores colocam que a estrutura geológica e a correspondente condição hidrogeológica podem ser fatores principais de controle na química de águas superficiais.

A parte superior do "bumerangue" do diagrama de Gibbs, representa águas cujo comportamento químico têm como mecanismo controlador a evaporação/cristalização; na parte central há o predomínio do mecanismo de interação água/rocha; na parte inferior o mecanismo ligado a precipitação é o que rege a química da água.

Os resultados obtidos neste estudo foram plotados no diagrama catiônico de Gibbs (1970) juntamente com os de outros estudos (Fig. 5). De um modo geral as amostras da área exibem comportamento similar às de outros estudos em áreas semiáridas a áridas do Brasil e do mundo (Silva Júnior et al., 1999; Pereira et al., 2006; Taheri et al., 2017; Qaisar et al., 2018; Zang et al., 2018; Zhang et al., 2019; Ma et al., 2019; Li et al., 2020).

As amostras do alto curso do rio do Mudo (M17, M18 e M32) estão no extremo do domínio do mecanismo evaporação/ cristalização; esse fato reforça a ideia já argumentada que a alta concentração iônica se deve à influência climática sazonal (período de estiagem e evaporação desses corpos hídricos), condicionando a um aumento da concentração salina. Águas superficiais e subterrâneas amostradas em ambiente desértico na Namíbia por Shanyengana et al. (2004) mostraram posicionamento parecido no Diagrama de Gibbs (Fig. 5, triângulos cheios), que plotam próximas a M17, M18 e M32; isso mostra como as condições de salinização das águas nos pontos supracitados são extremas, comparáveis às taxas de evaporação e salinização de ambientes desérticos, tendo as águas qualidade precária. Outros autores (e.g. Taheri et al., 2017 e Zhang et al., 2019) identificaram em áreas em clima árido a semiárido, características similares às aqui observadas. Isso mostra que, dentro desse regime climático, tendo em vista o Diagrama de Gibbs, o mecanismo que controla a química das águas é predominantemente o da evaporação e o da interação da água com as rochas, através dos processos de intemperismo.

As demais amostras (M22, M35, M36, M42 e M49) se apresentam próximas do limite ou fora do bumerangue, na porção intermediária dele. Pereira et al. (2006), estudando a salinidade de águas superficiais no estado do Ceará (Fig. 5, barras horizontais pretas), dizem que esse tipo de comportamento pode ser explicado pelo processo de precipitação/evaporação. Estas águas seriam derivadas das precipitações (campo inferior do bumerangue), pouco mineralizadas, 


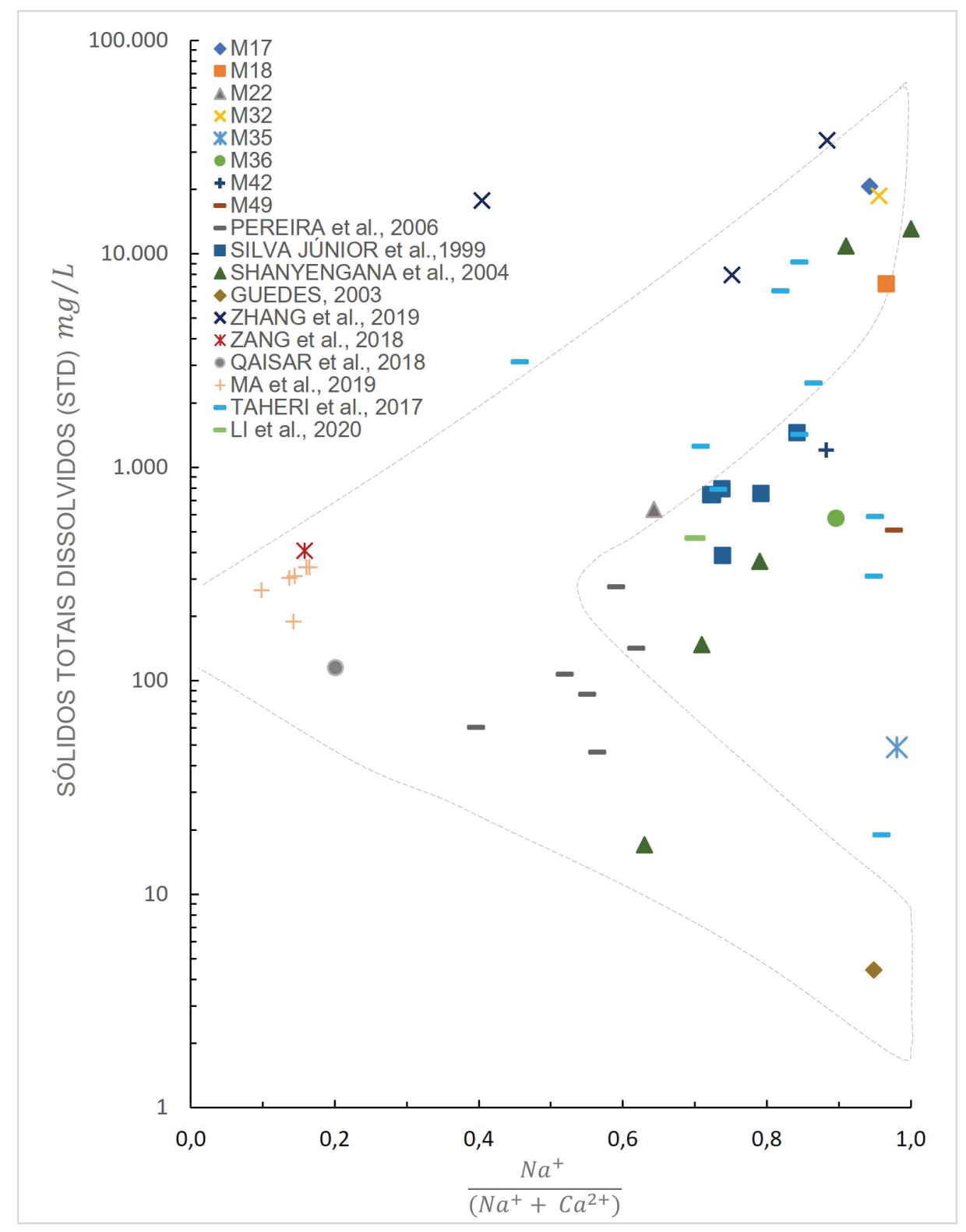

Figura 5. Diagrama catiônico de Gibbs (1970) para as amostras estudadas e outros estudos em águas superficiais no Nordeste do Brasil e no mundo. Os dados de água superficial são de Silva Júnior et al. (1999), Pereira et al. (2006), Qaisar et al. (2018), Zang et al. (2018), Ma et al. (2019), Zhang et al. (2019) e Li et al. (2020); dados de Taheri et al. (2017) são de águas superficiais e subterrâneas; dados de água de chuva em local próximo à área deste estudo e na Namíbia são de Guedes (2003) e Shanyengana et al. (2004), respectivamente.

Figure 5. Gibbs cation diagram for the samples studied and other studies in surface waters in the Northeast of Brazil and the world. The surface water data are by Silva Júnior et al. (1999), Pereira et al. (2006), Qaisar et al. (2018), Zang et al. (2018), Ma et al. (2019), Zhang et al. (2019) and Li et al. (2020); data from Taheri et al. (2017) are from surface and groundwater; rainfall data in a location near the area of this study, and in Namibia, are from Guedes (2003) and Shanyengana et al. (2004), respectively.

e mostram deslocamento vertical no diagrama devido à evaporação, sem sofrerem significativa mudança na composição química. O mecanismo recorrente de precipitação e rápida evaporação, que acarreta uma interação água/rocha menos expressiva e, consequentemente, águas menos mineralizadas, fica evidente nos resultados de Taheri et al. (2017) e Li et al. (2020) observado na Figura 5 (barras horizontais verdes e azuis).
As águas de poços e açudes no nordeste brasileiro estudadas por Silva Júnior et al. (1999), obtiveram resultados que foram plotados no diagrama de Gibbs (Fig. 5, quadrados azuis cheios). Eles mostram similaridades com as amostras desse trabalho e o argumentado por Pereira et al. (2006), evidenciando uma tendência para as águas submetidas a condições semiáridas sofrerem essa mudança 
no mecanismo de controle, passando de águas influenciadas pela precipitação, para o domínio do mecanismo de evaporação/cristalização. Alguns autores (e.g. Qaisar et al., 2018; Zang et al., 2018 e Ma et al., 2020) mostram que, em ambientes áridos a semiáridos, mesmo predominando a evaporação/cristalização para controle da química das águas, o maior período de interação com as rochas também pode ser um fator significativo.

Duas amostras de água de chuva também foram plotadas no diagrama de Gibbs; água de chuva de Macaíba, município localizado a cerca de 20 km ao sul da área estudada (Guedes, 2003), e da Namíbia (Shanyengana et al., 2004). Ambas se posicionam no campo inferior do Diagrama, em que o mecanismo de controle éa precipitação. Reforçam a ideia do comportamento proposto por Gibbs para águas oriundas de chuva, sendo pouco mineralizadas, mostrando baixos STD. Desta forma, as águas de baixa salinidade neste trecho ocidental/nascentes da bacia hidrográfica são indicativas da influência das chuvas (ou são as próprias águas de chuva acumuladas há pouco tempo), não estando associadas a ressurgência de águas doces subterrâneas do aquífero Barreiras, pois neste caso ocorre insaturação.

\subsection{Diagramas hidroquímicos}

\subsubsection{Piper}

Os locais de coleta das amostras M17, M18 e M32 estão no alto curso do rio do Mudo, diretamente sobre rochas graníticas da Suíte Intrusiva Dona Inês, descrita por Nascimento etal. (2008) como Calcialcalina de Alto K-Equigranular, sendo constituída por biotita (e/ou anfibólio) granitos a tonalitos, podendo os minerais constituintes contribuírem com a composição química das águas.

Leprun (1983) destaca que águas oriundas de regiões sedimentares, de baixa salinidade, são principalmente bicarbonatadas, sulfatadas ou mistas, enquanto nas fissuras das rochas pré-cambrianas do embasamento cristalino, com tendência a águas mais salinas, há predominância unicamente de águas cloretadas de sódio ou magnésio. Comportamento similar a este é observado nas amostras em estudo. Apesar da maioria das amostras se encaixar dentro da classificação cloretada sódica, o que se observa tanto no diagrama de Piper como nos demais que se seguem é um enriquecimento para $\mathrm{Na}^{+} \mathrm{e} \mathrm{Cl}^{-}$para as amostras relacionadas a rochas cristalinas (M17, M18 e M32); as demais amostras (M35, M36, M42 e M49), em locais com predominância de coberturas sedimentares, apresentam enriquecimento para $\mathrm{O}_{\mathrm{HCO}_{3}}^{-} \mathrm{e} \mathrm{Mg}^{2+}$.

Segundo Feitosa et al. (2008) o $\mathrm{Cl}^{-}$presente na água pode ser oriundo da lixiviação de camadas mais superficiais e da lixiviação de minerais ferromagnesianos de rochas ígneas, como a biotita e anfibólios, semelhantes às rochas encontradas na região. Nas águas subterrâneas o $\mathrm{Na}^{+}$pode ter como minerais fontes os plagioclásios, feldspatóides (nefelina e sodalita), anfibólios e piroxênios, minerais comuns em rochas ígneas.

A área em estudo situa-se em uma transição entre as Mesorregiões Agreste e Leste Potiguar, sofrendo influência do embasamento cristalino e das coberturas sedimentares mais recentes. Costa et al. (2006), em estudo sobre aspectos da salinização do aquífero cristalino do RN, mostra o elevado nível de salinização dos aquíferos relacionados ao ambiente cristalino. Ainda aponta a elevada presença de $\mathrm{Cl}^{-}$em toda a região do cristalino; contudo, os maiores núcleos de concentração estão relacionados ao Agreste Potiguar. O comportamento do $\mathrm{Na}^{+}$é similar ao observado para o $\mathrm{Cl}^{-}$.

As amostras M35, M36, M42 e M49 mostraram uma dispersão maior no diagrama de Piper. Ela é causada principalmente pelo aumento da concentração de $\mathrm{Ca}^{+2}, \mathrm{Mg}^{+2}$ e $\mathrm{CO}_{3}$ $2+\mathrm{HCO}_{3}^{-}$, em relação às amostras de água M17, M18 e M32. As amostras M35 e M49 se encontram sobre sedimentos aluvionares; esses podem apresentar minerais carbonatados, dentre outros resultantes ou não do intemperismo, tais como feldspatos e argilominerais, que podem ter influenciado nos teores dos íons citados nas amostras. As amostras M36 e M42 se encontram no alto curso do rio Guajiru, sobre influência dos granitos da Suíte Intrusiva Dona Inês, podendo ter essa condição sódica ligada aos plagioclásios 
e feldspatóides, minerais comuns de rochas graníticas, e sendo cloretada devido aos minerais ferromagnesianos constituintes dessas rochas, tais como biotita e anfibólios, semelhante ao ocorrido nas amostras do alto curso do rio do Mudo.

Costa et al. (2006) mostram que $\circ \mathrm{Ca}^{+2} \mathrm{e}$ o $\mathrm{Mg}^{+2}$ apresentam um comportamento similar quanto à distribuição espacial no RN. Ambos os íons apresentam seus valores mais elevados no aquífero cristalino na mesorregião do Agreste potiguar.

A amostra M22 foi classificada como cloretada mista, sendo águas que não apresentam concentração de um ânion ou cátion qualquer sobre os demais. A área de coleta está inserida em uma área urbana pouco habitada, composta por sedimentos aluvionares de canal.

O aspecto cloretado sódico da maioria das amostras condiz com os dados apresentados pelo IBGE (2007) para a região, onde a área em pesquisa está inserida em um contexto regional cujas águas subterrâneas são cloretadas sódicas, em transição para cloretadas mistas.

As águas amostradas dentro do domínio sedimentar (M22, M35, M36, M42 e M49) podem sofrer influência do aquífero Barreiras. Segundo Melo et al. (2005), é uma característica das águas desse aquífero, regionalmente ou na maior parte da faixa costeira leste do estado, a composição cloretada sódica.

Lucena et al. (2004), estudando o setor oriental da bacia do rio Pirangi/RN, constaram que a maioria das amostras estudadas no âmbito do aquífero Barreiras se apresentaram como cloretadas sódicas. Neste mesmo trabalho foram observadas variações, para mais, nas concentrações de $\mathrm{Ca}^{2+}, \mathrm{Mg}^{2+}$ e $\mathrm{HCO}_{3}{ }^{-}$. Apesar da característica cloretada sódica estar relacionada ao aquífero Barreiras (Melo et al., 2005), esse fator também se observa em ambientes do embasamento cristalino do estado. Medeiros (2004) mostrou, em estudo de uma microbacia na região Centro-Norte do $\mathrm{RN}$, a predominância da classe cloretada sódica para as análises realizadas em amostras do aquífero cristalino da área.

Shanyengana et al. (2004) estudando águas superficiais e subterrâneas na Namíbia, em condições semiáridas à áridas, utilizou o diagrama de Piper para classificar as amostras. Os autores encontraram águas de alta salinidade, classificadas como cloretadas sódicas em ambiente desértico nesse país. O estado de mineralização dos corpos do alto curso do rio do Mudo (M17, M18 e M32) é tal, que se compara sua salinidade à de ambientes desérticos, como os da Namíbia; isso mostra a relação do aumento da salinidade com ambientes semiáridos à áridos, e consequente diminuição da qualidade das águas. Padrões semelhantes de águas cloretadas sódicas foram encontrados em regiões áridas e semiáridas por autores como Taheri et al. (2017), Qaisar et al. (2018), Zhang et al. (2019), Ma et al. (2019) e Li et al. (2020), sugerindo que a condição climática interfere nessa classificação.

\subsubsection{Stiff}

É possível definir agrupamentos para as amostras. As amostras M17, M18 e M32, com concentrações mais expressivas no eixo representado por $\mathrm{Na}^{+}$e $\mathrm{Cl}^{-}$, e com a presença do íon $\mathrm{Mg}^{+2}$. Estão no mesmo contexto geológico dos granitos Dona Inês, sendo representativas dessa litologia (Fig. 3). As amostras M36, M42 e M49 formam outro agrupamento pelas similaridades nos diagramas, apresentando um enriquecimento no eixo horizontal intermediário que representa $\mathrm{Ca}^{+2}$ e $\mathrm{HCO}_{3}^{-}$. As amostras M36 e M42 estão inseridas no contexto dos granitos Dona Inês, podendo a origem do cálcio ser atribuída aos plagioclásios ou apatitas presentes nos granitos (Fig. 3). As amostras M22 e M35 são as mais distintas, ambas em contextos sedimentares. A M22 possui composição mais bicarbonatada, possivelmente proveniente dos minerais secundários nos sedimentos, e a M35 se apresenta mais sódica, possivelmente devido a decomposição de plagioclásios nos sedimentos (Fig. 3).

\section{1.3 Diagramas radiais}

Os diagramas radias mostram o relativo enriquecimento em $\mathrm{Cl}+\mathrm{e} \mathrm{Mg}^{+2}$ no grupo formado pelas amostras M17, M18 e M32. O íon magnésio pode ter como origem minerais ferromagnesianos 
como a hornblenda. 0 segundo grupo, formado pelas amostras M36, M42 e M49, apresenta concentrações mais expressivas nos eixos $\mathrm{CO}_{3}^{-2}$ $+\mathrm{HCO}_{3}$; $\mathrm{Cl}^{-} \mathrm{e} \mathrm{Mg}^{+2}$, apresentando enriquecimento nas espécies carbonatadas em relação às amostras anteriormente mencionadas. Aamostra M35 também não aparenta ter semelhanças químicas expressivas com as demais; mostra um enriquecimento de concentração na área do diagrama que corresponde a $\mathrm{Cl}^{-} \mathrm{e}$ $\mathrm{Mg}^{+2}$, semelhante ao primeiro grupo, mas um enriquecimento de $\mathrm{SO}_{4}^{-2}$ não observado nem no primeiro e nem no segundo grupos de amostras, podendo ser oriundo da oxidação do enxofre presente em algumas rochas e da lixiviação de compostos sulfatados como anidrita e gipsita. Ma et al. (2019) usando análise de coeficiente de correlação em estudo bacia no noroeste da China mostraram que $\mathrm{O} \mathrm{SO}_{4}^{-2}$ pode estar relacionado com as precipitações na região. No diagrama de Gibbs (Fig. 5) é visível que a amostra M35 é a que mais se aproxima das características de águas de precipitação atmosférica.

\subsection{Sólidos totais dissolvidos}

Com o STD medido das amostras foi possível observar que três das oito amostras (M17, M18 e M32) apresentaram STD medido maior que $1500 \mathrm{mg} / \mathrm{L}$, sendo classificadas como de características salgadas. Quatro das oito amostras (M22, M36, M42 e M49) apresentaram STD entre $500 \mathrm{mg} / \mathrm{L}$ e $1500 \mathrm{mg} / \mathrm{L}$, sendo definidas como salobras. Uma amostra (M35) apresentou STD entre $0 \mathrm{mg} / \mathrm{L}$ e $500 \mathrm{mg} / \mathrm{L}$, sendo definida como uma água doce. Como já argumentado, o período de estagnação dos corpos d'água nos quais foram coletadas as águas salgadas, bem como a escassez de chuva, podem ter influenciado no aumento da concentração de sais na água, elevando sua salinidade (M17, M18, M32). As demais amostras representam águas subterrâneas (M22 e M35) ou corpos d'agua com dimensões maiores e recebendo recarga a partir de aquíferos locais (M36, M42, M49). Os dados de Qaisar et al. (2018) para águas em regime árido à semiárido mostram altas concentrações de STD em amostras de águas superficiais; os autores apontam que esse fenômeno pode estar relacionado à condição climática e às maiores interferências antropogênicas em função do uso da terra.

\subsection{Razões iônicas}

Os resultados para razão iônica podem ser aplicados para tentar associar quimicamente o meio geológico percolado pelas águas, com sua assinatura química. Os resultados obtidos em relação a $\mathrm{rMg}^{+2} / \mathrm{rCa}^{+2}$ para a amostra M17 mostram, em suma, equivalência com águas marinhas, o que não condiz com a realidade, visto o local da amostragem ser no domínio continental fluvial do alto curso da bacia hidrográfica. A alta concentração dos íons provavelmente está ligada ao represamento da água e escassez de chuva, resultando no aumento progressivo da concentração salina. A razão $\mathrm{rMg}^{+2} / \mathrm{rCa}^{+2}$ para a amostra M22 indica uma equivalência a águas continentais, sendo coerente com o local da amostragem (médio curso da bacia) e com a presença do aquífero Barreiras, de onde provém a água. As demais amostras apresentam para a razão $\mathrm{rMg}^{+2} / \mathrm{rCa}^{+2}$ valores indicativos de relação das águas amostradas com litotipos ricos em silicatos magnesianos; provavelmente os granitos intrusivos na região da bacia contribuem com essa composição química da água.

Para a razão $\mathrm{CCa}^{+2} / \mathrm{rMg}^{+2}$ todas as amostras apresentaram valores que não indicam intrusão marinha o que corresponde perfeitamente com a região de trabalho, distante da costa, não ocorrendo o avanço da cunha salina. Para a razão $\mathrm{rK}^{+} / \mathrm{rNa}^{+}$os valores observados para a maioria das amostras foram valores entre 0,004 e 0,28, indicando águas doces. Entretanto, outras classificações, como a utilizada pelo software Qualigraf, apontam para a maioria das águas sendo salobras ou salgadas, não correspondendo ao resultado da razão exposta. Elas apresentam valores de STD de 500-1500 mg/L, ou superior a 1500 mg/L. A amostra M35 apresentou valor para essa razão da ordem de 0,02, indicando água do mar, resultado esse que não representa a amostra, a qual exibe uma concentração relativamente elevada para esses elementos. O valor para amostra M36 indicou água correspondente a circulação em rocha granítica, condizente com o ponto amostrado, uma região que está sobre a suíte intrusiva Dona 
Inês, que contribui para a química da água nesse ponto.

A razão iônica $\mathrm{rNa}^{+} / \mathrm{rCl}$ para todas as amostras, com exceção da M22, aponta para águas em contato e/ou circulando em domínio de rochas cristalinas ou vulcânicas. 0 alto curso da bacia ocorre no domínio de rochas granitognáissicas do embasamento cristalino précambriano, portanto, essa indicação da razão iônica mostra a influência dessas rochas na composição dessas águas.

Silva (2003), estudando a salinização em aquíferos fissurais no semiárido do $\mathrm{RN}$, mostra na região centro-norte do $\mathrm{RN}$ razões para $\mathrm{Na}+$ / $\mathrm{Cl}$ - semelhantes às da água do mar. Esse fato é explicado pela autora como influência dos aerossóis marinhos incorporados ao vapor d'água da atmosfera durante a evaporação da água do mar. Quando as nuvens adentram ao continente a precipitação faz com que esses componentes entrem em contato com a superfície, chegando aos reservatórios e aquíferos. A região do presente estudo está a cerca de $40 \mathrm{~km}$ da costa leste do estado. A elevação nos teores de alguns elementos responsáveis pelo aumento da salinidade e respectiva correlação com águas marinhas, pode também estar em parte relacionada com a influência dos aerossóis marinhos.

As águas estudadas (salgadas/salobras)na porção das nascentes da bacia demonstram que a sua salinização pode ter sido influenciada pelas condições de clima semiárido, considerando inclusive o que foi caracterizado por alguns autores como Leprun (1983), Silva Júnior et al. (1999), Silva et al. (2003), Lucena et al. (2004), Medeiros (2004), Shanyengana et al. (2004), Melo et al. (2005), Costa et al. (2006), Pereira et al. (2006), Stein (2013), e Jiang et al. (2015). Neste caso a salinização se dá pelo aumento da concentração salina decorrente da evaporação. Além disso, há também a hipótese de salinização das águas pelo contato água-rocha postulada por Hem (1986).

Observa-se que no setor ocidental (nascentes da bacia) existem também ocorrências de águas superficiais de baixa salinidade. Conforme comparação e análise da literatura, nestes casos as águas pouco salinas no domínio de rochas cristalinas granito- gnáissicas ou de coberturas pouco espessas do aquífero Barreiras, são indicativas da influência das chuvas, ou são as próprias águas de chuva acumuladas há pouco tempo, não estando associadas a ressurgência de águas doces subterrâneas do aquífero Barreiras, pois neste caso ocorre insaturado.

Desta forma, as águas salgadas/salobras das nascentes revelaram ser quimicamente muito distintas das águas superficiais do médio e baixo curso da bacia hidrográfica, nos quais têm-se o efeito da ressurgência das águas subterrâneas doces do aquífero Barreiras, que perenizam o vale/rios e a lagoa de Extremoz no médio/baixo curso, resultando em águas superficiais também doces/potáveis, usadas inclusive para consumo humano.

\section{Conclusões}

O diagrama dePiper classificouasamostras majoritariamente como cloretadas sódicas. Os diagramas de Stiff e os Radiais permitem ver uma correlação genética espacial entre as amostras. As do alto curso do rio do Mudo possuem semelhanças quanto aos diagramas, bem como as do rio Guajiru. Assim, é possível estabelecer entre elas e a região de nascente das sub bacias, bem como com a geologia, uma relação quanto a assinatura geoquímica e a origem dessas águas.
As
razões
iônicas
mostraram

predominantemente uma relação das amostras com litotipos ricos em silicatos magnesianos, rochas graníticas ou rochas cristalinas. Os valores refletem o substrato rochoso da região de alto e médio curso da bacia do rio Doce.

Os STDs apontaram uma predominância de águas salgadas para a bacia, não sendo atrativas para o consumo humano. A salinidade elevada das águas amostradas é atribuída a questões climáticas, devido ao período de seca vigente desde o ano de 2010 até o momento da amostragem (jul./ago. de 2016), fato esse que possibilita um aumento progressivo da concentração salina nas águas, bem como falta de renovação frequente; está também relacionada ao longo período de residência e interação das águas com o substrato rochoso.

Diante dos fatos constatados, as estratégias de planejamento de uso e de controle 
dos recursos hídricos superficiais da bacia devem levar em conta as diferentes assinaturas hidroquímicas daságuas superficiais nos distintos setores (nascentes/ocidental, ou médio/baixo curso/oriental) da bacia estudada. Nos setores ocidentais (nascentes), as águas mostraram-se mais salobras/salgadas por influência climática na concentração salina de sais por efeito da evaporação, e/ou salinização pelo contato água-rocha. Neste caso, as águas disponíveis devem ser usadas para fins domésticos menos nobres, uso animal, ou em alguns casos na irrigação de forma controlada. Caso se adotem processos de dessalinização (exemplo mediante osmose reversa), e dependendo das demandas e ofertas disponíveis, podem ser usadas para consumo humano. As águas de baixa salinidade neste trecho de nascentes, influenciadas diretamente pelas ocorrências de chuvas, podem localmente ser usadas para consumo humano ou outros usos mais nobres, desde que sejam tomadas precauções quanto a processos de contaminação.

Nos setores do médio/baixo curso/ oriental, as águas são de caráter doce/potável (lagoa de Extremoz e rio Doce), por influência do caráter ressurgente das águas subterrâneas do aquífero Barreiras, que perenizam esses setores com águas de melhor qualidade físico-química, doces e potáveis, e devem ter uso prioritário para consumo humano, com os devidos tratamentos e desinfecção, e para outros usos mais nobres.

Agradecimentos. ao CNPq pela concessão de bolsa de Produtividade em Pesquisa à segunda autora (Processo 311221/2015-7).

\section{Referências}

Aly, A. 2014. Hydrochemical characteristics of Egypt western desert oases groundwater. Arabian Journal of Geosciences, 8: 7551 7564

ANA. Agência Nacional de Águas. 2012. Estudos Hidrogeológicos para a Orientação do Manejo das Águas Subterrâneas da Região Metropolitana de Natal. 4 volumes. Brasília, ANA, 804p.

Azevedo Filho, J.B. Melo, J.V. de \& Lima, R.F. de S. 2012. Avaliação da Influência de Íons
Metálicos em Sedimentos de Fundo da Bacia Hidrográfica do Rio Doce, RN, Brasil. Revista Química no Brasil, 6 (1/2): 45-54.

Cajazeiras, C.C.A. 2007. Qualidade e Uso das Águas Subterrâneas e a Relação com Doenças de Veiculação Hídrica, Região de Crajubar/CE. Fortaleza, 131 p. Dissertação de Mestrado, Programa de Pesquisa e Pós-graduação em Geologia, Departamento de Geologia, Universidade Federal do Ceará.

CETESB. Companhia Ambiental do Estado de São Paulo. 2011. Guia nacional de coleta e preservação de amostras: água, sedimento, comunidades aquáticas e efluentes líquidos. São Paulo, CETESB; Brasília, ANA, 326p.

CONAMA. Conselho Nacional do Meio Ambiente. 2005. Resolução no 357, de 17 de março: dispõe sobre a classificação dos corpos de água e diretrizes ambientais para o seu enquadramento, bem como estabelece as condições e padrões de lançamento de efluentes, e dá outras providências. Brasília, CONAMA, 5p.

Costa, A.M. de B., Melo, J.G. de \& Silva, F.M. da. 2006. Aspectos da salinização das águas do aqüífero cristalino no estado do Rio Grande do Norte, Nordeste do Brasil. Águas Subterrâneas, 20(1): 67-82.

Costa, F.R. da., Souza, R.F. de \& Silva, S.M.P. da. 2016. Análise comparativa de metodologias aplicadas à delimitação da bacia hidrográfica do rio Doce - RN. Sociedade \& Natureza, 28(3): 429-442.

CPRM. Companhia de Pesquisa de Recursos Minerais. 2012. Carta geológica folha Natal; Brasília, Ministério de Minas e Energia, Secretaria de Geologia, Mineração e Transformação Mineral, escala 1:100.000.

CPRM. Companhia de Pesquisa de Recursos Minerais. 2013. Carta geológica da folha João Câmara. Brasília, Ministério de Minas e Energia, Secretaria de Geologia, Mineração e Transformação Mineral, escala 1:100.000.

Cunha, S.B. da. \& Guerra, A.J.T. 2012. Degradação Ambiental. In: GUERRA, A.J.T. e CUNHA, S.B. da (Org.). Geomorfologia e Meio ambiente. Rio de Janeiro: Bertrand Brasil, p. 337-374.

Custódio, E. \& Llamas, M.R. 1983. Hidrologia Subterrânea. Barcelona, Ediciones Omega, 1157p. 
Eaton, A.D., Clesceri, L.S., Greenberg, A.E. \& Franson, M.A.H. 1998. Standard Methods for the examination of water and wastewater. Washington.

Faustino, A.B., Ramos, F.F. \& Silva, S.M.P. da. 2014. Dinâmica temporal do uso e cobertura do solo na Bacia Hidrográfica do Rio Doce (RN) com base em Sensoriamento Remoto e SIG: uma contribuição aos estudos ambientais. Sociedade e Território, 26(2): 18-30.

Feitosa, F.A.C. 2008. Hidrogeologia: Conceitos e Aplicações. Rio de Janeiro, CPRM-LABHID, $812 p$.

Fenzl, N. 1986. Introdução à hidrogeoquímica por Norbert Fenzl e a colaboração de J.F. Ramos. Belém, Universidade Federal do Pará, 189p.

FUNCEME. Fundação Cearense de Meteorologia e Recursos Hídricos. 2017. Qualigraf. Disponível em: $\quad$ <http://www3.funceme.br/qualigraf/>. Acesso em 10 ago. 2017.

Gastmans, D., Alberto, M.C., Bufon, A.G.M., Moraes, F.T., Santos, M.M., Silva, J.R.M. \& Chang, H.K. 2005. Implicações hidroquímicas da interação rocha-água: interpretações através da representação gráfica de análises químicas de águas subterrâneas. In: ENCONTRO NACIONAL DE PERFURADORES DE POÇOS, 14 \& SIMPÓSIO DE HIDROGEOLOGIA DO SUDESTE, 2., 2005, São Paulo. Anais... São Paulo, p. 1-18.

Gibbs, R.J. 1970. Mechanisms Controlling World Water Chemistry. Science, New Series, 170(3962): 1088-1090.

Guedes, J. de A. 2003. Diagnóstico geoquímico e ambiental do rio Jundiaí nas imediações da cidade de Macaíba/RN. Natal, 120p. Dissertação de Mestrado, Programa de Pesquisa e Pós-graduação em Geociências, Centro de Ciências Exatas e da Terra, Universidade Federal do Rio Grande do Norte.

Hamad, A., Baali, F., Hadji, R. 2017. Hydrogeochemical characterization of water mineralization in Tebessa-Kasserine karst system (Tuniso-Algerian Transboundry basin). Euro-Mediterr J Environ Integration, 3, article 7 (2018).

Hem, J.D. 1986. Study and interpretation of the Chemical Characteristics of Natural Waters: Water Suply Paper 2254. Alexandria: U.S. Geological Survey, 253p. Disponível em: < http://pubs.usgs.gov/wsp/wsp2254/pdf/ wsp2254a.pdf > Acesso em 15 fev. 2017.

IBGE. Instituto Brasileiro de Geografia e Estatística. 2007. Hidroquímica dos Mananciais Subterrâneos, Folha SB.25V-C. Brasília, Ministério do Planejamento, Orçamento e Gestão, Diretoria de Geociências. Escala 1:250.000.

Jiang, L., Yao, Z., Liu, Z., Wang, R. \& Wu, S. 2015. Hydrochemistry an its controlling factors of rivers in the source region of the Yangtze River on the Tibetan Plateau. Journal of Geochemical Exploration, 155: 76-83.

Leprun, J.C. 1983. Primeira avaliação das águas superficiais do Nordeste. Relatório de fim de convênio de manejo e conservação de solos do Nordeste brasileiro. Recife, SUDENE, 50p.

Li, X., Zhang, Y., Wu, T., Sun, X., Yang, T., Wang, L., Li, X., Wang, J., Wang, Y. \& Yu, H. 2020. Major ions in drinking and surface waters from five cities in arid and semi-arid areas, NW China: spatial occurrence, water chemistry, and potential anthropogenic inputs. Environmental Science and Pollution Research, 27: 5456-5468.

Lima, W. de P. 1976. Princípios de manejo de bacias hidrográficas. Piracicaba: ESALQ/DS, USP, 150p.

Logan, J., 1965. Interpretação de Análises Químicas da Água. US. Recife, Agency for International Development, 75p.

Lucena, L.R.F. de, Rosa Filho, E.F. da \& Bittencourt, A.V.L. 2004. Características hidroquímicas do aqüífero Barreiras no âmbito do setor oriental da bacia do rio Pirangi-RN. Revista Águas Subterrâneas, 18: 29-38.

Ma, H., Zhu, G., Zhang, Y., Pan, H., Guo, H., Jia, W., Zhou, J., Yong, L., \& Wan, Q. 2019. The effects of runoff on Hydrochemistry in the Qilian Mountains: a case study of Xiying River Basin. Environmental Earth Sciences, 78: 385-395.

Medeiros, J. da S. 2004. Análise dos fatores que influenciam na alta salinidade dos aqüiíferos fissurais da bacia do Riacho do Feijão Pedro Avelino/RN. Natal, 85p. Dissertação de Mestrado, Programa de Pesquisa e PósGraduação em Geociências, Centro de Ciências Exatas e da Terra, Universidade Federal do Rio Grande do Norte.

Melo, J.G.de, Oliveira, J.A.de, Lopes, V.L., Diniz Filho, J.B., Vasconcelos, M.B. \& Silva, F. H.R.da. 
2005. Avaliação integrada dos recursos de águas subterrâneas e superficiais da bacia do rio Boqueirão, a oeste de Touros, RN. Revista Águas Subterrâneas, 19(2): 121-136.

Nascimento, M.A.L., Medeiros, V.C. \& Galindo, A.C. 2008. Magmatismo ediacarano a cambriano no domínio Rio Grande do Norte, província Borborema, NE do Brasil. IG. Série B, Estudos e Pesquisas, 18: 4-25.

Neissi, L., Tishehzan, P. \& Albaji, M. 2019. Chemical assessment of surface water quality in upstream and downstream of Jare Dam, Khuzestan, Iran. Environ Earth Sciences, 78, article 83 (2019).

Nobrega, T.F., Souza, R.F. de \& Medeiros, G.F. 2017. Avaliação ecotoxicológica de água e sedimento de um reservatório de água urbano e costeiro do nordeste brasileiro. Ambiência Guarapuava, 13(2): 393-411.

Oliveira, J.B. de. 2006. Diagnóstico geoquímico de água e sedimento de fundo da Lagoa de Extremoz - região da grande Natal-RN. Natal, 128p. Dissertação de Mestrado, Programa de Pesquisa e Pós-graduação em Geociências, Centro de Ciências Exatas e da Terra, Universidade Federal do Rio Grande do Norte.

Pereira, L., Santiago, M.M.F., Frischkorn, H., Araújo, J.C. de \& Lima, J.O.G. de. 2006. A salinidade das águas superficiais e subterrâneas na bacia da Gameleira, município de Aiuaba/CE. Revista Águas Subterrâneas, 20(2): 9-18.

Qaisar, F.U.R., Zhang, F., Pant, R.R., Wang, G., Khan, S. \& Zeng, C. Spatial variation, source identification, and quality assessment of surface water geochemical composition in the Indus River Basin, Pakistan. 2018. Environmental Science and Pollution Research, 25: 12749-12763.

Sakram, G. \& Adimalla, N. 2018. Hydrogeochemical characterization and assessment of water suitability for drinking and irrigation in crystalline rocks of Mothkur region, Telangana State, South India. Applied Water Science, 8 article 143 (2018).

Shanyengana, E.S., Seely, M.K. \& Sanderson, R.D. 2004. Major-ion chemistry and groundwater salinization in ephemeral foodplains in some arid regions of Namibia. Journal of arid environments, 57: 71-83.

Silva Júnior, L.G.de A., Gheyi, H.R. \& Medeiros, J.F. de. 1999. Composição química de águas do cristalino do Nordeste brasileiro. Revista Brasileira de Engenharia Agrícola e Ambiental, 3(1): 11-17.

Silva, S.G. 2003a. Aqüíferos fissurais em clima semi-árido (caso do estado do RN, NE do Brasil): uma análise dos processos de salinização em escala regional e local. Rio Claro, 166p. Tese de Doutorado, Programa de Pós-Graduação em Geociências e Meio Ambiente, Instituto de Geociências e Ciências Exatas, Universidade Estadual Paulista "Júlio de Mesquita Filho".

Silva, S.G. 2003b. Análise dos fatores responsáveis pela salinização dos aqüíferos fissurais do cristalino: Caso da região de Serra Negra. In: SIMPÓSIO DE GEOLOGIA DO NORDESTE, 20, Resumo... Fortaleza, p.150.

Stein, P. 2013. Hidrogeoquímica das águas subterrâneas da Bacia Sedimentar Potiguar/ RN e caracterização da salinização do aquífero Cárstico Jandaíra. Recife, 204p. Tese de Doutorado, Programa de Pós-Graduação em Geociências, Centro de Tecnologia e Geociências, Universidade Federal de Pernambuco.

Taheri, M., Gharaie, M.H.M., Mehrzad, J., Afshari, R. \& Datta, S. 2017. Hydrogeochemical and isotopic evaluation of arsenic contaminated waters in an argillic alteration zone. Journal of Geochemical Exploration, 175: 1-10.

Zhang, B.; Zhao, D.; Zhou, P.; Qu, S.; Liao, F. \& Wang, G. 2020. Hydrochemical Characteristics of Groundwater and Dominant Water-Rock Interactions in the Delingha Area, Qaidam Basin, Northwest China. Water, 12 (3), 836851.

Zhang, Y., Zhu, G., Ma, H., Yang, J., Pan, H., Guo, H., Wan, Q. \& Yong, L. 2019. Effects of Ecological Water Conveyance on the Hydrochemistry of a Terminal Lake in an Inland River: A Case Study of Qingtu Lake in the Shiyang River Basin. 2019. Water, 11(8): 1673-1689.

Manuscrito 102566 | Recebido em abr. de 2020 | Aceito em out. de 2020 | Editor: Iran C. S. Corrêa 